NBER WORKING PAPER SERIES

U.S. FOREIGN-EXCHANGE-MARKET INTERVENTION AND THE EARLY DOLLAR FLOAT: $1973-1981$

Michael D. Bordo

Owen F. Humpage

Anna J. Schwartz

Working Paper 16647

http://www.nber.org/papers/w16647

NATIONAL BUREAU OF ECONOMIC RESEARCH

1050 Massachusetts Avenue

Cambridge, MA 02138

December 2010

The authors thank Michael Shenk, and Zebo Zakir for their research assistance. The views expressed herein are those of the authors and do not necessarily reflect the view of the National Bureau of Economic Research.

NBER working papers are circulated for discussion and comment purposes. They have not been peerreviewed or been subject to the review by the NBER Board of Directors that accompanies official NBER publications.

(C) 2010 by Michael D. Bordo, Owen F. Humpage, and Anna J. Schwartz. All rights reserved. Short sections of text, not to exceed two paragraphs, may be quoted without explicit permission provided that full credit, including $(\mathcal{O}$ notice, is given to the source. 
U.S. Foreign-Exchange-Market Intervention and the Early Dollar Float: 1973 - 1981

Michael D. Bordo, Owen F. Humpage, and Anna J. Schwartz

NBER Working Paper No. 16647

December 2010

JEL No. F3,N1,N2

\begin{abstract}
$\underline{\text { ABSTRACT }}$
The dollar's depreciation during the early floating rate period, 1973 - 1981, was a symptom of the Great Inflation. In that environment, sterilized foreign exchange interventions were ineffective in halting the dollar's decline, but showed a limited ability to smooth dollar movements. Only after the Volcker FOMC changed its monetary-policy approach and demonstrated a willingness to maintain a disinflationary stance despite severe economic weakness and high unemployment did the dollar begin a sustained appreciation. Also contributing to the ineffectiveness of the interventions was the Desk's method of operation. The small, covert interventions, particularly prior to 1977, seemed inconsistent with an expectations channel of influence, and financing intervention with short-term borrowed funds seemed inconsistent with a portfolio-balance channel of influence. The Desk never clearly articulated an intervention transmission mechanism. The episode indicated the shortcomings of sterilized intervention and led to their cessation in April 1981.
\end{abstract}

Michael D. Bordo

Department of Economics

Rutgers University

New Jersey Hall

75 Hamilton Street

New Brunswick, NJ 08901

and NBER

bordo@econ.rutgers.edu

Owen F. Humpage

Federal Reserve Bank of Cleveland

P.O. Box 6387

Cleveland, OH 44101-1387

owen.f.humpage@clev.frb.org
Anna J. Schwartz

NBER

365 Fifth Ave, 5th Floor

New York, NY 10016-4309

aschwartz@gc.cuny.edu 


\title{
U.S. Intervention and the Early Dollar Float: 1973 - 1981
}

\author{
“There's an adage in the marketplace that says one should always go \\ against an intervention, since any intervention reflects an inherent \\ weakness in the currency being supported. "
}

(The Wall Street Journal, 3 August 1983, p. 3)

\section{Introduction}

On 12 March 1973, the Bretton Woods fixed-parity system effectively ended when eight key European industrialized countries instituted a joint float against the dollar. In doing so, they joined Canada, Italy, Japan, Switzerland, and the United Kingdom, which already had allowed their currencies to float unilaterally against the dollar. Most monetary authorities at the time grudgingly accepted floating as a necessary step to a restructured international monetary system based once again on fixed exchange rates. In the interim, they thought, floating could raise the cost of speculation, which the February 1973 dollar depreciation had greatly encouraged, and-most importantlycould limit the substantial inflows of unwanted dollar liquidity stemming from persistent U.S. inflation and balance-of-payments deficits. ${ }^{1}$

The international community, of course, never returned to fixed-dollar exchange rates. Initially, bad U.S. monetary policy and a persistently high U.S. inflation rate, the disparate impact of oil price shocks, and idiosyncratic business-cycle patterns made a return to a parity system impossible. Eventually, private markets adjusted to the volatility of floating rates, and policy makers realized that floating exchange rates fostered macroeconomic stability better than fixed exchange rates and did so with no obvious cost to international trade or investment. Under floating, countries continued to cooperate on international monetary matters; they did not revert-as was often fearedto the beggar-thy-neighbor policies of the 1930s.

Although monetary authorities eventually accepted floating exchange rates, they continued to view the market as inherently prone to bouts of disorder. Monetary authorities never clearly articulated the market failure underlying this alleged disorder, but they seemed to believe that information imperfections could cause exchange rates to deviate from their fundamental values, create excessive volatility, and foster destabilizing speculation. Under such conditions, they contended, foreign-exchange intervention could help direct exchange rates along a path consistent with fundamentals and could do so with lower volatility than otherwise would be the case. An official presence, particularly on the part of the United States, was necessary to maintain market order.

The record of U.S. operations between March 1973 and April 1981, however, was equivocal at best. The United States intervened almost exclusively in support of the dollar, but during nearly every operation, the dollar continued to depreciate. To be sure, U.S. interventions at the time often sought only to smooth dollar movements, not to prevent or reverse them. $^{2}$ On this score, we offer some limited evidence of success. Still, the overall record led many observers and practitioners to question the usefulness of sterilized intervention. 
U.S. interventions during the early floating-rate period are best understood as reflections of the monetary policy of the era. The period covers most of the Great Inflation episode, America's longest period of peace-time inflation and arguably the Federal Reserve System's biggest policy failure after the Great Depression. The renewed acceleration of U.S. inflation in late 1977, after repeated attempts to rein it in, seriously weakened the credibility in U.S. monetary policy. It prompted a sharp dollar depreciation, which eventually challenged beliefs in the efficacy of sterilized intervention. By August 1979, monetary policy began to change under the direction of Federal Reserve Chairman Paul Volcker, and by April 1981, U.S. intervention operations all but stopped with the urging of the Under Secretary of the Treasury for Monetary Affairs Beryl Sprinkle.

\section{The Great Inflation: 1965 - 1980}

Exchange rates are endogenous variables that respond to, and help propagate the impact of unanticipated economic developments. In the face of a shock, exchange rates arguably may undershoot or overshoot their equilibrium values in the short run, but ultimately their steady-state paths reflect economic fundamentals. When monetary authorities intervene, particularly when they intervene over long periods of time, they are reacting to whatever economic events sent the exchange-rate along a path that they found undesirable. In that sense, prolonged sterilized intervention is often a reflection of some fundamental underlying economic occurrence, such as inappropriate monetary policy (see Sprinkel, Testimony, 1981, p. 16). Any analysis of intervention requires an understanding of the basic macroeconomic developments occurring in concert with the operation. Active interventions during the early floating rate period, especially after 1976, by and large attempted to attenuate the dollar's persistent depreciation, which itself was primarily a symptom of the Great Inflation.

During the early 1960s, the Bretton Woods system constrained U.S. monetary policy and anchored inflation expectations. ${ }^{3}$ Under a dollar peg, inflation could deteriorate the U.S. balance-of-payments position and eventually undermine the official dollar price of gold. Because the private sector understood this constraint, inflation expectations did not respond to shocks, and inflation demonstrated little inertia. This check on U.S. monetary policy was not particularly important during the dollar-shortage period of the Bretton Woods era, roughly 1949 through early 1958, since the world needed dollar reserves. The constraint began to bind in the early 1960s, as the many foreign central banks that held excessive amounts of dollars increasingly demanded gold. As explained in chapter 4, in the early 1960s, the U.S. Treasury and the Federal Reserve established many ad hoc policies to limit the drain on U.S. gold reserves, thereby, weakening the constraint and allowing policymakers-notably the Federal Reservegreater latitude to pursue domestic objectives.

America's Great Inflation began in late 1965 and lasted through 1980, when the disinflation policies of the Volcker FOMC finally began to take hold. Inflation started to accelerate in late 1965 and rose above 2\% on a year-over-year basis in early 1966 (see figure 1). In contrast, between 1960 and 1965, inflation had averaged only 1.2\% per year with relatively little variation. During the Great Inflation, inflation cycled upwards in three big movements, first reaching a $61 \frac{1}{2} \%$ annual rate in early 1970 before subsiding, then climbing above a $12 \%$ annual rate in 1974 before again slowing, and finally 
attaining a 141/2\% annual rate in 1980. As with each cyclical peak, each cyclical trough was higher than its predecessor. According to contemporary accounts, inflation expectations became a problem for policy makers by 1969 (see Hetzel 2008, p. 75). By late 1976, worldwide confidence in the ability and willingness of the Federal Reserve System to control inflation was quickly waning. By early 1977, the dollar, which had depreciated on balance since the inception of generalized floating, came under even stronger downward pressure, and by 1978, international investors were moving funds out of dollar-denominated assets.

The Great Inflation occurred because the Federal Reserve failed to pursue a policy of price stability. Instead, monetary policy became exceptionally easy from 1966 through 1968, again from 1970 through 1972, and finally throughout the last half of the 1970s (see figure 2). Economic historians have attributed the pursuit of these policies primarily to the adoption of a faulty economic framework, one that downplayed money's causal role in the inflation process, but a policy preference for low unemployment over low inflation, mismeasurement, and political pressures also contributed to the System's dysfunction.

With the ascendancy of Keynesian economics by 1960, policymakers began to distinguish between demand-pull inflation and cost-push (or structural) inflation (see Hetzel 2008). Demand-pull inflation resulted when aggregate demand, as measured by actual GDP, exceeded aggregate supply, as measured by potential GDP. (Alternatively, aggregate demand exceeded aggregate supply when the unemployment rate fell below its natural rate, generally pegged at 4 percent in the 1960s and 1970s.) According to the then conventional model, if the economy were operating below potential, demand-pull inflation could not be a problem, except possibly for some lingering inertial effects that would eventually dissipate. The proper role of macroeconomic policy was to return GDP quickly to its potential growth path and to restore full employment. As Hetzel (2008) emphasizes, this framework induced a stop-go quality to policy, which decimated inflation expectations.

Mainstream Keynesian economists saw demand-pull inflation as stemming from excess aggregate demand and not from excess money growth per se. Within this framework, either a budget surplus or tight monetary policy could reduce inflation, but because tight monetary policy raised interest rates, whereas tight fiscal policy did not, fiscal policy remained the tool of choice for demand management at least until the early 1970s (Hetzel 2008, pp. 80-81). Monetary policy was to manage interest rates either in support of fiscal policies or in actions like Operation Twist. Beginning around 1970, however, the importance of monetary policy began to rise relative to that of fiscal policy (Hetzel 2008, pp. 79).

Within the conventional model, any inflation that existed when economic activity fell below potential must be of the cost-push variety. Chief among the causes of costpush inflation were union wage demands, but monopoly-pricing power, commodity-price shocks, dollar depreciations, and myriad other ad hoc price pressures contributed to costpush inflation. Demand management_fiscal and monetary policies_could do nothing about cost-push inflation short of pushing the economy into a protracted recession, and should, therefore, not attempt to offset it. Eliminating cost-push inflation required some type of incomes policy. Consistent with this prescription, the Kennedy administration 
pursued wage and price guidelines; the Nixon administration used direct price freezes and controls, and the Carter administration attempted price guidelines.

Complicating matters, especially during the 1960s, economists believed that they could permanently lower the unemployment rate by accepting a higher inflation rate (see Romer and Romer 2002, p. 24). According to Mayer (1999, pp. 122-124), many economists and policymakers believed that inflation was not as socially disruptive as unemployment. He attributes this belief partly to economists' experience with the Great Depression and partly to their lack of experience with peace-time inflations. Hetzel (2008, p. 65, 67), sounding a similar chord, contends that the social unrest of the 1960s and 1970s had policymakers fearful about high unemployment. ${ }^{4}$ They often regarded an unemployment rate high enough to eliminate inflation as politically infeasible (Hetzel 2008, p. 111).

Policy makers, of course, could only achieve a trade-off between lower unemployment and higher inflation to the extent that the public formed expectations about inflation from past experience and not from beliefs about future economic developments. Policy makers assumed this and initial evidence seemed to confirm it. Given the low and stable inflation rates of the 1960s, inflation expectations were slow to build after 1965. In the early 1970s, however, economists began to amend this view and to worry about inflation expectations.

The Great Inflation proved hard to overcome because heightened inflation expectations eventually increased the output and employment costs of any subsequent disinflationary policy, and the Administration and the Federal Reserve became increasingly reluctant to incur these costs. Chari, Christiano and Eichenbaum (1998) and Christiano and Gust (2000) refer to this as an expectations trap. The greater the concern that a central bank shows for real economic developments, the more likely it becomes that the central bank can fall into the expectations trap.

Basing policy on a split between demand-pull and cost-push inflation requires reliable measurement. Romer and Romer (2000), Orphanides (2002, 2003), and Clarida, et al. (2000) have argued that the System's poor policy performance during the Great Inflation resulted in large measure because policymakers consistently underestimated the natural rate of unemployment or, equivalently, consistently overestimated the level and growth rate of potential output. Such estimation errors would lead policymakers to underpredict inflation, to incorrectly attribute any observed inflation to cost-push factors, and to pursue a monetary policy that was excessively accommodative.

Two hallmark events of the 1970s undoubtedly contributed to measurement errors. First, sharp hikes in relative oil prices lowered structural productivity growth and potential output. ${ }^{5}$ Second, unprecedented shifts in labor participation rates raised the natural rate of unemployment. Together lower structural productivity growth and a higher natural rate of unemployment would lower potential output. According to current Congressional Budget Office (CBO) estimates, potential GDP grew at an average annual rate of $4.0 \%$ between 1947 and 1973, but over the next 10 years potential grew on average at less than half this rate (1.2\%). Moreover for most of this period, the administration put the natural rate of unemployment at $4 \%$, but subsequent CBO's estimate indicate that the natural rate continually rose, reaching a peak of $6.3 \%$ in 1978 . 
Given the substantial relative-price shocks and structural changes taking place in the 1970s, it is not surprising that policymakers overestimated the nation's potential growth path and underestimated the natural rate of unemployment.

With the perception that the economy was often below potential or that unemployment was too high, the administration often exerted pressure on the Federal Reserve to accommodate fiscal expansions by keeping interest rates low (see Meltzer 2005). Chairmen Martin and Burns viewed the Federal Reserve System as independent within the government, not independent of the government. By this, they meant that the System should not undertake actions that might thwart the administration's ability to achieve its policy objectives, such as low unemployment. As a consequence, the System often delayed tightening monetary policy in the face of rising inflation or reversed direction when the unemployment rate rose to avoid administration and Congressional criticism. Not until the Volcker chairmanship in 1979 would the System recognize inflation as a monetary phenomenon and clearly assert its independence to pursue price stability. In the mean time, the dollar depreciated broadly in foreign-exchange markets.

\section{Providing Guidance: U.S. Intervention 1973- 1977}

After an initial sharp depreciation in the months immediately following the inception of generalized floating, the dollar remained fairly stable through mid 1977, despite the run-up in U.S. inflation (see figures 1 and 3). Still, U.S. policymakers regarded floating exchange rates as inherently prone to disorder. In their view, the private sector processed information inefficiently, which caused excessive exchange-rate volatility and prolonged disparities between observed rates and their equilibrium values as determined by economic fundamentals. Intervention, according to the official view, was necessary to provide market guidance and to calm market disorder.

Exactly how officials thought intervention achieved market calm is unclear; they never clearly articulated a theoretical channel of influence. Although many staff economists discussed intervention within the context of a portfolio-balance model, the Foreign Exchange Desk viewed intervention as having a "psychological” effect on the market that came about because the intervention expressed an official concern for exchange rates. The Desk, however, never equated this view with a modern expectations channel, through which the Desk might aid price discovery by signaling new private information to the market.

As we will show, the operations seemed wholly out of place with either of these channels. By and large, the interventions were financed through short-term swap borrowings, which the Desk quickly repaid, thereby offsetting any portfolio effect. The Desk also kept the transactions small and undertook them covertly out of a fear that private market participants would bet against the System and possibly overwhelm an operation. If the Desk had an informational advantage over the market, however, large overt operations would seem necessary to signal that information. At best, the Desk may have simply attempted to trick some market participants into believing that others had changed their perceptions, but this does not seem consistent with expressing official concern for exchange rates.

In any event, the operations had some limited effect on exchange-rate movements. Intervention to purchases and sales of foreign exchange did not result respectively in 
dollar depreciations or appreciations. In fact, market participants could have profitably bet against System operations. The interventions, however, seemed sometimes to smooth dollar movements.

\section{The Advent of Floating}

Despite the dollar devaluation in December 1971, the Bretton Woods system continued to unravel. ${ }^{6}$ The U.S. balance-of-payments position improved somewhat after the devaluation, but it continued to show large overall deficits. U.S. inflation had moderated somewhat in 1970 and 1971, but at 3.3\% in mid-1972, it remained substantially higher than in the early 1960s. By 1973, the U.S. inflation rate was again starting to rise and soon exceeded the inflation rate in Germany-the key European country (see figure 4). Cross-border financial flows grew and seemed increasingly sensitive to interest-rate differentials and speculative prospects. Foreign countriesnotably Germany and Japan-continued to intervene heavily and to amass unwanted dollar reserves, which created for them excessive domestic liquidity. Inflation in Germany was around 5\% to 6\% in 1972 and accelerating, while inflation in Japan was quickly approaching double-digit levels.

In January and early February 1973, as speculation against the dollar intensified, the Foreign Exchange Desk at the Federal Reserve Bank of New York sold \$318.6 million worth of German marks in the New York market, with roughly 15\% of the total for the U.S. Treasury's account. To finance its portion, the System used up its entire portfolio of \$167.4 million equivalent German marks and borrowed \$104.6 million worth of marks from its swap line with the Bundesbank. The System also sold \$20.4 million worth of its Netherlands guilders. ${ }^{7}$ Despite its size, the intervention had little effect, and the situation continued to deteriorate.

On 12 February 1973, the United States devalued the dollar for a second time, by raising the official price of gold from $\$ 38$ per ounce to $\$ 42.22$ per ounce. This devaluation brought the total dollar depreciation since 1971 to $151 / 2 \%$ on a trade-weighted basis against the G10 currencies, an amount that many officials thought sufficient to correct the U.S. balance-of-payments problem (de Vries, 1985, p. 67). U.S. officials also indicated that they would phase out controls on financial flows by the end of 1974, about the time that they expected the devaluation to improve the U.S. balance-of-payments position. $^{8}$

Private markets were not so sanguine about the dollar's prospects and speculation against the dollar intensified. As Charles Coombs, the Special Manager of the Federal Reserve Bank of New York's Foreign Exchange Desk, noted, the second devaluation taught all of those holding dollars "a harsh lesson," and they were rapidly positioning themselves not to be caught off guard again (FOMC, Minutes, 7 March 1973, p. 3). Gold, at \$100 per ounce, was selling well above the new official price of \$42 per ounce, which suggested a good chance for a further dollar depreciation. Adding fuel to the speculative fire, U.S. authorities indicated that they would not intervene in defense of the new parities; they would follow the old Bretton Woods custom of leaving that task to other countries.

In response to the second dollar devaluation, Italy and Japan immediately floated their currencies. On 1 March 1973, the Bundesbank acquired \$3.7 billion, the largest 
amount ever bought or sold by a central bank in a single day, and on 2 March, the Bank of France bought \$580 million in just 90 minutes (de Vries, 1985, p. 76). With speculation rampant, the European exchange markets quickly closed.

On 12 March 1973, Belgium, France, Germany, Luxemburg, and the Netherlands agreed to a joint float against the dollar — the snake (see: Solomon, 1982, p. 218). A year earlier, the six European Economic Community countries had decided to limit fluctuations in their exchange rates to $2 \frac{1}{4} \%$ through intervention in each other's currencies - the snake in the tunnel. ${ }^{9}$ They would finance their operations through shortterm borrowing arrangements with settlement in prescribed reserve assets. A country in the snake would intervene in dollars only when its exchange rate was at the edge of the band; otherwise all intervention was in the constituent currencies. As part of the March 1973 agreement, Germany revalued the mark by 3\% against the SDR. On 20 March 1973, Norway and Sweden joined the joint float. Although this effectively ended the Bretton Woods system, policy makers at the time viewed the float against the dollar only as a necessary interim mechanism toward the reformation of Bretton Woods. Talks were already underway.

In July 1972, the international financial community had established the Committee of Twenty within the International Monetary Fund to reform the Bretton Woods system. ${ }^{10}$ Although participants generally favored a system based on set parities, they knew that any new exchange-rate system would need to be more flexible than its predecessor. Greater flexibility could be achieved within a fixed-but-adjustable rate system through wider margins around the parities and more frequent central-rate adjustments. Indicators based on changes in countries' reserve holdings or on their basic balance-of-payments trends might promote greater flexibility by de-politicizing parity changes and by ensuring that surplus countries shared in the adjustment burden (de Vries 1985, pp. 163-197 and Solomon 1982, pp. 235-266).

By early 1973, most monetary officials also expressed a tolerance for-if not an outright acceptance of-temporarily floating exchange rates. ${ }^{11}$ In the current circumstances of heightened speculation, large international imbalances, more fluid financial movements, and excessive worldwide liquidity, fixed exchange rates were simply unworkable. A temporary reliance on floating rates was necessary.

Few, however, believed that an international monetary system based on floating exchange rates was sustainable. Many feared that the uncertainties inherent to floating rates would discourage international trade and investment, and they worried that floating rates would promote the same disruptive policies-protectionism and competitive depreciations - that characterized the 1930s. Some, including Federal Reserve Chairman Arthur Burns, extrapolating these fears, believed that floating would promote the formation of currency blocs or-worse still—would lead to a complete breakdown of international monetary cooperation and financial order among nations (Burns, July 1973, pp. 510-11).

Nevertheless, in the wake of the oil price shocks of December 1973 and the huge payments imbalances that they portended, the industrial countries were unwilling to commit to parities anytime soon. In January 1974, the Committee of Twenty ceased its reform efforts. With floating rates continuing for the foreseeable future, the IMF set out 
instead to develop procedures that might maintain a cooperative international monetary environment.

In June 1974, the IMF proposed guidelines for floating exchange rates, which, despite their objective, revealed a clear preference for fixed exchange rates and presumed a heavy central bank presence in the market. The IMF guidelines recommended day-today or week-to-week interventions to prevent or moderate erratic fluctuations in exchange rates. The guidelines also condoned intermediate-term interventions (monthto-month or quarter-to-quarter) to moderate longer-term-but temporary-movements in rates. The IMF objected to aggressive, beggar-thy-neighbor interventions. A central bank was not to buy foreign exchange when its currency was depreciating over the intermediate term nor sell foreign exchange when its currency was appreciating over the intermediate term. The guidelines also recognized that some member countries might operate floating rates within a target-zone framework and suggested that such countries consult with the IMF about the target. In addition, the IMF recommended that member states with floating rates discuss with them the broad objectives for their official-reserve policies. These guidelines, however, were never fully implemented in part because of different views about how to do so and in part because some Executive Directors of the IMF felt that the guidelines put a bigger consultation and information burden on members with floating rates than on members with fixed rates (de Vries, 1985, pp. 297-302).

Many nations, particularly France and most developing countries, still favored a return to fixed exchange rates, but events in the mid 1970s continued to overtake reform efforts. By 1975, the U.S. position under Treasury Secretary William Simon, with prodding from the U.S. Congress, was shifting in favor of long-term floating (Solomon, 1982, p. 269). The Rambouillet meeting of the Group of Seven nations on 15-17 November 1975 became a compromise of sorts between the U.S. and French views. Participants rewrote IMF Article IV, allowing countries to choose floating in the longterm, but leaving open the possibility of a return to a fixed-exchange-rate system with greater flexibility than Bretton Woods. Policy makers, moreover, were quickly eradicating the central role of gold in the international monetary system (Schwartz, 1983, pp. 34-36). Gold would not anchor any future fixed-rate system. The Rambouillet communiqué emphasized the need for exchange-rate stability but saw stability as the product of "orderly underlying economic and financial fundamentals." Supportive official actions to counter disorderly market conditions were welcome, but nations should not attempt to impose stability at a particular rate or to 'manipulate' exchange rates for advantage (Volcker and Gyohten 1992, p.141; Solomon 1982, p. 274). U.S. officials saw Rambouillet as requiring the United States to become more active in the foreign exchange market - especially to counter "erratic movements” in rates — and to quickly establish a mechanism for day-to-day consultation (FOMC, Minutes, 16 December 1975, pp. 3-6).

\section{Market Failure and the Role of Intervention}

Despite their growing approval of a generalized floating regime during the 1970s, U.S. monetary authorities were unwilling to give the private market free reign in determining exchange rates. They considered foreign-exchange markets prone to disorderly conditions, as revealed through price volatility, cumulative or self-propagating exchange-rate movements, wide bid-ask spreads, and fairly persistent exchange-rate 
deviations from fundamentals. The market, in their view, required official guidance. As Coombs once complained, he had, "little hope that market forces can be relied upon to restore orderly markets and to maintain an appropriate exchange rate structure.” (FOMC, Minutes, 19-20 November 1973, p. 31)

U.S. policymakers were never explicit about the exact nature of the underlying market failure. In part-at least initially - they seemed to view the market, particularly the New York market, as being underdeveloped. Greene (\#127, August 1984, p. 5) pointed out that in late 1974 most U.S. multinationals conducted their exchange business abroad and that most U.S. banks maintained their key foreign-exchange operations abroad. Under Bretton Woods, the dollar became the key international vehicle currency, easily enabling U.S. banks to specialize in providing liquid dollar markets, not foreignexchange facilities. Moreover, under the parity system, hedging against exchange-rate fluctuations was not the make-or-break priority that it became under floating. The failures of both the Herstatt and Franklin National banks in 1974 because of foreignexchange exposures dramatically illustrated to policymakers the problem of learning to operate in the new regime. The Herstatt failure led to a "marked drop in foreign exchange market activity as participants grew wary of credit risk.” (Dooley and Shafer 1983, p. 48) These bank failures caused both bank management and governments to restrict banks' ability to take open positions, contributing - along with a general uncertainty about future monetary policies-to a lack of sufficient stabilizing private speculation (McKinnon 1976).

More fundamentally, however, U.S. policymakers seemed to believe that information imperfections plagued the foreign-exchange market. In a fairly common description of market activity, the Foreign Exchange Desk at the Federal Reserve Bank of New York observed that, "Traders ignored fundamental factors that would normally favor the dollar.” (Bulletin, December 1977, p. 1049). From the Desk’s view, information imperfections-like traders' ignorance of fundamentals-caused exchange rates to deviate from their equilibrium values, created excessive volatility, and fostered destabilizing speculation. Tests undertaken at the Board of Governors in 1976 seemed to reject the martingale model of exchange rates, suggesting that market participants did not use information efficiently (Dooley and Shafer 1976, 1983).

Although U.S. monetary officials believed that intervention could repair these reoccurring market failures, the FOMC never discussed a transmission mechanism in public documents like the FOMC Minutes, or the Bulletin's reports on “Treasury and Federal Reserve Foreign-Exchange Operations.” Theoretically, intervention can affect exchange rates through a monetary mechanism, a portfolio-balance channel, and an expectations effect, as explained in chapter 1.

Economists have often wondered if central banks during the early floating exchange rate period completely sterilized their operations, thereby closing down any monetary channel. In the 1970s, both the staff and the FOMC understood the important distinction between sterilized and non-sterilized intervention, and the System routinely sterilized all foreign-exchange operations (see: Morton and Truman, 1979, p. 12; Truman, 1980, p. 10; Adams and Henderson, 1983, p. 1; Greene, \#127, August 1984, p. 16). As Truman (1980, p. 10) explained: "If the Federal Reserve intervenes to counteract [a] rise in the exchange value of the dollar, it will buy marks and sell dollars. 
The dollars sold will add to the public's holdings of U.S. Treasury securities because the intervention's potential expansionary impact on the U.S. money supply is automatically offset in daily open market operations." In the case that Truman describes, the Desk would sell Treasury securities to the public to offset its injection of dollar reserves. "[T]he net effect of the intervention is to increase the supply of dollar-denominated assets and decrease the supply of mark-denominated assets available to private asset holders...” (Truman, 1980, p. 10) Desk foreign-exchange operations during the early dollar float did not affect reserves in the U.S. banking System.

Complete sterilization, as Adams and Henderson (1983, p. 1) emphasized, "leaves the monetary liabilities of both home and foreign authorities unchanged.” [Emphasis added.] Truman (1980, p. 10) assumes, "that the Bundesbank also takes action to keep the German money supply unchanged...” But, prior to the 1980s, many industrialized countries, including Germany, did not have well-developed money markets and did not conduct monetary policy through open-market operations. They relied instead on discount-window operations. Consequently, these banks may not have been able to sterilize foreign-exchange operations on a day-to-day basis. Indeed, as our narrative indicates, foreign central banks were often worried about the excess liquidity resulting from official U.S. intervention sales of their currencies. Consequently, some temporary or partial monetary transmission mechanism may often have been in play.

Sterilized intervention can affect exchange rates independent of monetary policy through a portfolio-balance channel. Truman (1980) and the studies accompanying the Jurgenson Report indicate that the staff recognized the possibility of a portfolio-balance mechanism during the early floating-rate period. Adams and Henderson (1983), for example, offer a definition of sterilized intervention that strictly conforms to a portfoliobalance mechanism. What ultimately matters in their definition is a change in central banks' holdings of net foreign assets. Neither the specific type of foreign-currency transaction nor its motive carries much weight in their definition. The net effect of an intervention, as Truman (1980, p. 10) explained, is to alter the relative stocks of dollardenominated and foreign-currency denominated securities that the public holds. If the public views these securities as imperfect substitutes, they might only alter their portfolios if offered a risk premium for the more abundant security. This risk premium could easily come about from a change in the spot exchange rate in the desired direction, see chapter 1.

Whereas the Board's economic research staff seemed to describe intervention as possibly operating through at least two macroeconomic mechanisms - the monetary and portfolio-balance channels - the Foreign Exchange Desk never mentioned them. The Desk only referred to intervention's effect on market psychology. The FOMC Minutes provide an example: “...the basic objective, Mr. Coombs observed, would be to influence market psychology, by providing evidence of official interest and concern...[W]ith some good fortune, System operations could make a very important contribution.” (FOMC, Minutes, 9 July 1973, p. 8) This and similar statements seem broadly consistent with a modern expectations channel, through which monetary authorities convey private information useful to price discovery, but the Desk's statements typically relied on a show of "official interest and concern," or on "evidencing a sense of responsibility for the dollar" rather than on the transmission of new 
information (FOMC, Minutes, 9 July 1973, p. 13). Moreover, both Coombs and Federal Reserve Bank of New York President Alfred Hays thought intervention needed to be part of an unspecified broader program that relied heavily on direct controls over financial flows (FOMC Minutes, 7, March 1973, pp. 8-12). Consequently, why they thought sterilized U.S. intervention offered the United States an independent policy instrument with which to affect exchange rates remains unclear.

\section{The U.S. Returns to the Market}

On 16 March 1973, the G10 Finance Ministers agreed that foreign-exchange intervention was useful to maintain orderly markets within a regime of floating exchange rates. $^{12}$ The Europeans thought that U.S. participation was particularly important for the success of such efforts. For its part, the United States remained decidedly lukewarm about the prospects of intervention, but agreed in principle to such operations. The United States had not intervened since the closing of the gold window on 15 August 1971, except for a brief operation in July 1972, and the aforementioned support operations prior to the 12 February 1973 dollar devaluation. Neither of these actions was particularly successful, but the United States' current concern about intervention centered on its financing, not on misgivings about its recent effectiveness.

Holding the United States back was the lack of a clear arrangement for risk sharing under the existing swap facilities (FOMC Minutes, 19-20 March 1973, pp. 63-4). In March 1973, the United States held virtually no foreign-exchange reserves and would need to draw on its swap lines to finance its interventions (see figure 5 and 6). Given the growing magnitude of cross-border financial flows, an expansion of the swap network also seemed necessary. In March 1973, Charles Coombs recommended an increase of roughly 50\% to the $\$ 11.7$ billion network (FOMC Minutes, 19-20 March 1973, p. 73) (see figure 7).

For the most part, the swap lines had remained dormant because of continuing disagreements about the distribution of currency losses associated with the dollar's devaluation and with the move to floating. ${ }^{13}$ The swap lines traditionally maintained revaluation clauses, which protected debtor countries should the creditor country revalue its currency, but the swap lines contained no clear provisions for losses resulting from a general dollar devaluation - a change in the official gold price - or from the adoption of a float. Consequently, the United States conceivably faced large losses on Belgian franc, British sterling, German mark, and Swiss franc drawings outstanding prior to 15 August 1971.

On 8 July 1973, as an inducement to undertake intervention, Belgium, France, Germany, the Netherlands, and Switzerland agreed to risk sharing arrangements with the United States (Task Force Paper \#9, 24 January 1990, p. 6). ${ }^{14}$ Henceforth, when the Federal Reserve drew on a swap line for intervention purposes, it would share any valuation profit or loss equally with the creditor bank. With the risk-sharing issue settled, the System increased the swap lines on 10 July 1973, from $\$ 11.7$ billion to nearly $\$ 19$ billion and renewed its intervention operations. ${ }^{15}$

The risk sharing arrangement did not apply to foreign central bank drawings on the swap lines (Task Force Paper \#9, 24 January 1990, p. 6). When a foreign government drew on the line, it bore the entire risk. ${ }^{16}$ In January 1974, officials at the 
Bank of Italy sought an increase in their swap line from \$2 billion to \$3 billion. Concerned about the international ramifications of the recent oil price hikes, Chairman Burns supported the increase, but he suggested that under the new line, the Bank of Italy assume all of the exchange risk. Moreover, Burns suggested-apparently with the U.S. Treasury's approval-that the System announce its willingness to expand the swap lines of other countries under the same terms (FOMC Minutes January 22, 1974, pp. 33-51). In March 1974, Britain asked for a \$1 billion increase in its swap line to \$3.0 billion and agreed to assume all of the exchange risk associated with its subsequent drawings (FOMC Minutes March 13, 1974, pp. 54-65).

As with the use of the swap lines, the objective and mechanics of U.S. intervention under a floating exchange-rate regime would necessarily be substantially different than they had been under Bretton Woods. U.S. intervention under the Bretton Woods system primarily sought to provide central banks with cover for their dollar exposures and thereby to dissuade them from converting unwanted dollar balances into gold with the U.S. Treasury. The task of intervening to keep specific exchange rates within their Bretton Wood parity bounds usually fell to foreign central banks (see chapter 4). After 15 August 1971, protecting the gold stock was not an issue, and with the advent of generalized floating, calming market disorder became the oft-stated objective.

Between 12 March 1973 and 17 April 1981, the Desk operated on both sides of the market, but by and large, it only actively intervened to alleviate downward pressure on the dollar. By actively intervened, we mean that the Desk transacted with the clear intention of affecting dollar exchange rates. The Desk conducted the lion's share of this intervention against German marks but occasionally undertook small operations in Belgian francs, French francs, Japanese yen, Netherlands guilder, and Swiss francs. The German mark acted as the linchpin of the snake, so an intervention that altered the markdollar rate might easily affect all of the European currency rates vis-à-vis the dollar.

Because the United States financed most its intervention sales of foreign exchange by borrowing, soon after an operation, the Desk needed to repurchase foreign exchange to pay down outstanding U.S. obligations. For the most part, the Desk did not consider these purchases to be interventions: "[W]hen the Desk was acquiring currencies to repay debt, it tried to avoid having any noticeable influence on the market. Operations conducted with a view to influencing market psychology in the hope of affecting exchange rates might more properly be described as 'intervention.'” (FOMC, Minutes, 15 July 1975, p. 8) Likewise, after 1979, the Desk began to buy foreign exchange to build a larger reserve portfolio. Although the Desk did not undertake transactions to pay down debt or to accumulate reserves with the goal of affecting exchange rates - and therefore, did not actively intervene in these cases - the Desk often timed these operations to minimize or maximize their impact in the market. The Desk might avoid or delay transacting in the market by acquiring foreign exchange off-market with some other central bank or by rolling over the swap drawing. By timing the market transaction, the Desk passively intervened as Adams and Henderson (1983) explain. ${ }^{17}$

The Foreign Exchange Desk operated in close consultation with the Board and FOMC. Early in the day, the Desk informed the Board staff of any plans for intervention, and throughout the day, it maintained close communications. If the interventions were large, the Desk also solicited the Subcommittee's views on the operation. The 
Subcommittee was responsible to the entire FOMC (FOMC, Minutes, 20 May 1975, pp. 17-8). The FOMC, which was ultimately responsible for intervention, issued instructions to the Desk. A foreign-currency authorization set overall limits on the System's net open position, and procedural instructions spelled out how the Desk might approach its overall limits. Informal limits also governed how much of specific currencies the Desk might hold within the overall authorization, and the Treasury and the Desk maintained "implicit tactical day-to-day limits.” (FOMC, Transcripts, 21 October 1981, p. 7)

The Desk also cooperated closely with other central banks, particularly after the Rambouillet agreement. Each day beginning in December 1975, a central bank from a European Community country called the Federal Reserve Bank of New York at 11:00 a.m. with a summary of exchange rates, intervention, and market conditions in Europe. The Desk immediately relayed that information to the Bank of Japan-through its New York office - and the Bank of Canada. At the close of the New York market, the Desk sent all of these central banks a cable informing them of New York closing exchange rates, U.S. intervention, and market commentary (FOMC, Minutes, 12 December 1975, pp. 5-6). The Desk also worked out the upper-limit of its intervention amounts with the appropriate central banks.

The Federal Reserve Bank of New York adopted various techniques for intervention, depending on the degree of secrecy that the Desk wanted to maintain, its budget for intervention, and the market effect that the Desk hoped to achieve. ${ }^{18}$ During the 1970s, the Desk appears to have conducted most of its interventions covertly (Hooper 1977, p. 7). This was especially true before 1979. Early on, the United States usually intervened on a relatively limited scale because of its small portfolio of foreign exchange. The operations remained secret because the Desk feared that with only a limited portfolio, market participants could easily take a position against the Fed and foil the intervention operation if they knew that the Fed was in the market. If knowledge of the System's operations spread, the effect would be all the more intense and might actually force the Desk to withdraw from the market (Hooper, 1977, p. 8).

Ironically, however, the covert operations that Hooper describes seem inconsistent with the Desk's stated view that interventions were useful to affect market psychology by demonstrating "official interest and concern," for the dollar or by "evidencing a sense of responsibility for the dollar." At best, except for their small scale, these operations seem more consistent with a portfolio-balance channel of influence. As noted, the Desk and the FOMC never clearly articulated how they thought sterilized intervention worked.

In New York during the early 1970s, most foreign-exchange transactionsincluding interventions —-went through the brokers' market. Brokers maintained direct telephone lines with the largest foreign-exchange trading banks. They did not undertake transactions for their own accounts, but matched bids and offers in a highly competitive market for small fixed commissions. Consequently, the transactions costs of operating in the brokers' market for both the Fed and private traders were significantly less than dealing on a bilateral basis.

When the System wanted to undertake a covert operation, it asked a trader at a commercial bank to act as the agent for the Desk in the New York brokers' market. The 
broker arranged a trade and only afterward revealed the buying and selling parties — in this case, only two commercial traders, one of whom confidentially acted on behalf of the Desk. This mode of operation not only kept the Desk's identity secret, but it lent the Federal Reserve the expertise of a day-to-day commercial practitioner, and the commercial bank assumed the credit risk associated with the transaction. In return, the System typically paid the commercial bank a small commission (0.003 per cent) on the value of the transaction (Hooper, 1977, p. 6). Hence a typical intervention of \$15 million yielded the trader $\$ 45$ thousand.

In the 1970s, the Fed normally intervened through one of 25 major U.S. dealing banks out of the roughly 200 banks that operated in the New York brokers' market (Hooper, 1977, p. 3). The System maintained direct telephone contacts with these banks. When intervening, the System usually operated only with an individual bank for a single day (Hooper, 1977, p. 4). The frequency with which the System called on a particular bank reflected the quality of its service, which consisted mainly of providing the Desk with current market information. The Desk generally felt that these correspondents offered much better information than it acquired through its more routine telephone contacts with dealers. In addition to maintaining anonymity and to providing information, operating in the brokers' market through a commercial bank allowed the Desk to settle in federal funds, whereas operating directly with a broker would require the Desk to settle in clearing-house funds (Hooper 1977 p. 7).

The apparent intent of a covert operation was simply to trick one side of the market about the intensity of private actions on the other side of the market; that is, to make one side of the market believe that the other was trading on new information. The conjecture apparently was that traders are more likely to respond favorably to a stabilizing transaction if they believe that the demand emanates from the private sector rather than from U.S. monetary authorities. As noted in the quote at the beginning of this chapter, the market sometimes interpreted official intervention transactions as evidence of fundamental weakness in a currency. Given that the Desk generally worked with individual banks for a single day, intervention lasting for a long number of days was likely to become widely known in the market—at least among the key banks (Hooper, 1977, p. 4). Hence, to remain secret, most intervention operations needed to be of fairly short duration.

The Desk often finessed its transaction amounts and its pricing strategy to get the biggest bang for its buck. Pardee (1973) discussed a number of strategies. When the dollar was depreciating, for example, the Desk might probe the strength of demand for a foreign currency by placing an offer (to sell) somewhat above the typical offer rate and then observing how bidders (to buy) responded. If traders take the high offer, it suggests a stronger demand for the foreign currency than if they reject or counter the offer. The Desk also varied the size of its transactions to the same end, but unusually large transactions ran the risk of tipping the Federal Reserve's hand to the market (Pardee, 1973, p. 6). Typically the Desk acted to counter market trends or "lean against the wind," but it sometimes sought to reinforce or to reverse them. The possibilities and permutations were large, as Pardee (1973) suggests. As discussed below, in early 1981, the Desk even attempted to bracket the dollar's volatility by simultaneously placing bid 
and offer prices in the market, and it sometimes operated on both sides of the market even on a single day. ${ }^{19}$

On some occasions in February 1975 and frequently after 1979, the Desk wanted the market to know that it was actively trading, particularly if it sought to intervene forcefully. Then, the Desk placed large orders with the brokers' market or directly with particular banks. Pardee (1973, p. 6) reports that, "This knowledge alone can have a profound psychological effect, and could move the dollar to stronger ground without heavy intervention on our part.” By late 1977, as we will see below, the Desk began intervening more openly and in larger amounts. On 4 January 1978 and for a few days hence, the Desk placed orders to sell marks directly with several New York commercial banks, and the mark depreciated immediately without the Desk actually selling a single mark (Bulletin, March 1978, p. 166). In addition, the Desk sometimes tried to enhance the operation by timing it to coincide with a favorable news item or economic release, or by also announcing the operation to the press. Unfortunately, as we will see, the Desk's actions did not always conform to the underlying thrust of U.S. monetary policy. So it is not always clear whether the Desk added signal or noise to the market.

Commercial banks that acted as agents for the Desk also could benefit in terms of their own transactions from their knowledge of the System's intervention (Task Force Paper \#5, 18 January 1990, p. 13). The Desk expected banks that executed its transactions to do so promptly, to maintain confidentiality, and not to undertake offsetting transactions. As we will see, however, the evidence suggests that banks often seemed to interpret Desk sales of foreign exchange as a signal to buy.

As noted, in addition to pure intervention, the Desk undertook two other types of foreign-exchange transactions in the market. The Desk bought foreign exchange to repay swap borrowing and to build foreign-exchange reserves. (Often the Desk bought foreign exchange directly from foreign central banks or from other correspondents off market for this purpose.) The Desk also executed market transactions for foreign correspondents that maintained accounts with the Federal Reserve Bank of New York. When not going off-market, the Desk usually dealt directly with commercial banks when undertaking these types of transactions for two reasons: Often these transactions did not occur in the standard amounts that the brokers' market handled and if the System entered the brokers' market directly, it might have been forced to acknowledge and reject the credit risk associated with a specific commercial bank. The number of banks that the Desk dealt with for these non-intervention transactions included the 25 U.S. banks through which the System intervened plus 5 other foreign-owned banks that resided in the United States (Hooper 1977, pp. 8-10).

\section{Were U.S. Interventions between March 1973 and September 1977 Effective?}

Although U.S. inflation generally rose and the dollar tended to depreciate between March 1973 and September 1977, the dollar's overall downward trend was quite modest, and confidence in the dollar remained fairly firm for the most part. The October 1973 OPEC oil embargo and the associated price hikes generally seemed to bolster the dollar even though they prompted a recession and a sharp easing in U.S. monetary policy during 1974. After rising precipitously throughout much of 1973, the real federal funds rate fell sharply in the wake of the oil shock and remained negative throughout much of 1977. 
Observers, however, generally thought that the United States would be less susceptible to the adverse effects of oil-price shocks than other industrialized countries, and this perception often bolstered demand for the dollar. For one thing, OPEC priced oil in dollars. Since demand for oil was inelastic, the demand for dollars to pay for oil would likely rise. In addition, many thought that the dollar would likely benefit more than most other currencies from the recycling of oil revenues. The oil price increase also caused foreign central banks to hold more dollars in their portfolios, thereby reducing the dollar "overhang" that followed the August 1971 closing of the U.S. gold window.

Despite the overall confidence in the dollar, the Desk intervened fairly frequently. In addition, the period witnessed some very sharp swings in the dollar, particularly relative to the German mark, and the Desk undertook four sizable intervention episodes (see figure 8). Specific events triggered these four key intervention episodes: a revaluation of the German mark within the European joint float in late June 1973, the liberalization of barriers on financial flows in January 1974, a rapid easing of U.S. monetary policy in October 1974, and further European joint-float problems in early 1976. ${ }^{20}$ Table 1 empirically describes these operations.

These early interventions were much smaller in scale than the active U.S. interventions after September 1977, and not very persistent, with the exception of the operations in early 1975. The Desk initiated each of the operations and undertook almost all of the interventions for the System's own account. While the Treasury consented to the System's actions, it rarely participated. ${ }^{21}$ The Desk intervened primarily against German marks, but it also transacted in Belgian francs, French francs, Swiss francs, Netherlands guilder, and, on only two occasions, in Japanese yen. The Desk usually undertook interventions in non-German European currencies because of developments in the European joint float. In early 1975, for example, when the German mark was at the bottom of the European joint float, the Bundesbank did not want the Desk to undertake heavy mark sales, so the Desk transacted a lot in Netherlands guilder and Belgian francs, which were at the top of the joint float (FOMC Minutes 20 May 1975, p. 13).

Because the System had exhausted its German mark balances in early 1973, it financed these mark sales primarily by drawing on its swap line with the Bundesbank. Consequently, the Desk had to quickly acquire dollars to pay down its swap obligations once market conditions improved. The Desk acquired almost all of the marks for this purpose in the market, but was also able to obtain marks off-market at various times from central bank correspondents (Greene \#127, pp. 14 - 15).

Over the 1184 business days between 2 March 1973 and 14 September 1977, the United States intervened on 337 days against German marks (see table 2). On 161 of these intervention days, the United States sold marks, and on 176 days, the United States bought marks. A typical (median) mark sale equaled nearly \$14 million equivalent, but the largest amounted to \$104 million equivalent. The operations were not very persistent, with roughly one half lasting only a single day. Almost all lasted less than three consecutive days, but one operation persisted for 13 days. A typical mark purchase was slightly smaller than a sale. The median equaled $\$ 10$ million equivalent, with the largest equal to $\$ 65.3$ million equivalent. As with mark sales, most operations to buy marks lasted only a single consecutive day, with almost all persisting less than four days. The longest operation lasted 15 consecutive days. 
We evaluate the effectiveness of these U.S. interventions according to three success criteria: The first asks if U.S. sales or purchases of German marks on a specific day were respectively associated with a same-day dollar appreciation or depreciation against the mark. The second criterion asks if U.S. interventions moderated movements in the dollar vis à vis the mark over the day of the intervention relative to mark-dollar exchange-rate movements on the previous day. If, for example, official U.S. sales of German marks on a specific day were associated with a slower rate of dollar depreciation over that day as compared with the dollar depreciation on the previous day, we considered that intervention a success. The third success criterion combines the previous two into a single measure. (See our methodological appendix.)

These success criteria seem consistent with the stated objectives of intervention during the early dollar float. As already noted, managers from the Federal Reserve Bank of New York's Foreign Exchange Desk often indicated that they did not try to defend a specific exchange rate. They instead only tried to moderate movements or limit fluctuation in exchange rates (see Pardee (1973); Green \#127 August 1984, p.8; FOMC, Minutes 19-20, March 1973, p.67; FOMC Minutes, 17 April 1973, p.58). Pardee (1973) also indicated that the Desk sometimes sought to reinforce or reverse exchange-rate trends. Moreover, FOMC participants and Congressmen sometimes wondered whether U.S. operations were attempting to prop up a specific rate (FOMC Minutes 19 February 1975, p. 21, FOMC Minutes 18 March 1975, pp. 9-11, and FOMC Minutes 20 May 1975, p.13).

We next count the number of successes under each criterion and compare that count with the number that we would randomly anticipate given the volatile nature of day-to-day exchange-rate movements. This comparison assumes that the success counts are hypergeometric random variables (see appendix).

This methodology does not specify a theoretical channel through which intervention operates, but seems most consistent with an expectations channel. We assume that neither a monetary mechanism nor a portfolio-balance channel was in effect. The latter assumption seems reasonable given the paucity of evidence in favor of a portfolio-balance effect. The former assumption may be problematic, given the domestic liquidity problems that foreign central banks experienced in defending the dollar. A violation of either assumption should bias our success counts upward, in favor of intervention affecting exchange-rate movements.

Only 45 (or 28\%) of the 161 U.S sales of German marks prior to 14 September 1977 were associated with a same-day dollar appreciation against the mark. In a sample of 1184 observations, however, we would expect to observe 74 successes (that is $46 \%$ of the interventions) purely by chance. The observed number of successes falls well below two standard deviations from the expected number, suggesting that U.S. intervention sales of German marks were a fairly reliable signal that the dollar would depreciate against the mark, and implying — as the adage at the start of this chapter suggests - that market participants could have profited from selling dollars, if they knew that the System was intervening. $^{22}$

Our analysis of official U.S. purchases of German marks is no different than that of sales. As already noted, however, the Desk typically undertook mark purchases over 
this period for purposes other than trying to manage exchange rates. Although the Desk may have timed these transactions to minimize or maximize their impact on the market, our analysis of their success suggests that official mark purchases provided a fairly accurate signal that the dollar would appreciate. As with sales, market participants that knew of the intervention could have profitably bet against the Desk.

When we evaluate U.S. interventions over this period in terms of moderating movements in the dollar, the picture is substantially more favorable to the idea that intervention can affect exchange rates. Of the 161 U.S. sales of German marks prior to 14 September 1977, 34 (or 21\%) were associated with a slower pace of dollar depreciation on the day of the intervention than over the previous day. This count is more than two standard deviations above the number (21) that we expect to randomly observe. Our analysis of the largely passive U.S. purchases of German marks produces similar results. All and all, roughly 23 percent of the intervention successfully smoothed exchange-rate movements. Still, this is a fairly small proportion of the total interventions.

When we combine these two criteria into a single criterion-presuming that we do not know which criterion the Desk was attempting to achieve on any specific day-the results suggest that intervention had no better than a random impact on exchange-rate movements. Successful U.S. sales of German marks (79) fall more than two standard deviations below the expected number (94), and although the observed number of successful U.S. purchases of German marks (112) slightly exceeds the expected number (107), the difference is not statistically significant. All and all, only $49 \%$ of the active interventions to support the dollar and only $64 \%$ of the passive interventions to acquire German marks were successful under any criterion.

Coombs, in a post-operation assessment of the July 1973 episode, suggested that he was limited in his activities (FOMC Minutes, 21 August 1973, pp. 14-17). He feared that interventions in excess of \$50 million on any given day would weaken the Treasury's support for the System's operations. Indeed, as shown above, a typical intervention was well below this amount. He felt that the scale of operations "on certain days" should have been $\$ 100$ to $\$ 125$ million.

The U.S. interventions between March 1973 and early September 1977 were small in scope, generally covert, and not closely coordinated-a combination not likely to have a strong impact on the market. Still, the key problem with the active intervention operations to support the dollar after 1973 was that they conflicted with the general tenor of U.S. monetary policy. At the same time that the Desk sold German marks and other foreign currencies into the New York market, the System maintained an excessively easy monetary policy that fueled the Great Inflation. 


\section{The Dollar in Crisis: October 1977 through July 1980}

The years 1977 through 1981 were some of the most turbulent in the Federal Reserve's post-war history, culminating in a major change to monetary policy and in serious questions about the efficacy of foreign-exchange-market intervention. Between late 1977 and mid 1980, U.S. intervention unsuccessfully attempted to mitigate the exchange-rate consequences of a rapidly rising U.S. inflation rate. Inflation in the United States increased over these years, while inflation in many other key developed countries—notably Germany—moderated (see figure 4). In response, the Federal Reserve System raised its key policy rates beginning in 1977, but overall the System "remained sensitive to the possibility that a rapid firming in interest rates might prematurely put at risk the economic expansion” (Greene, \#128, October 1984, p. 7). Consequently, the real federal funds rate remained near zero until late in 1979, and dipped below zero again in mid-1980 when economic activity contracted (see figure 2). As confidence in the System's efforts to rein in inflation eroded, the pace of the dollar's depreciation quickened.

Over this period, the foreign-exchange market was expanding — becoming increasingly sophisticated and more globally integrated. ${ }^{23}$ Multinationals were centralizing their exchange-rate decisions at their headquarters, typically in the United States. Consequently, the U.S. foreign-exchange market was growing rapidly. U.S. banks expanded their foreign-exchange operations and many foreign banks opened branches in the United States. Daily turnover in the global foreign-exchange market, which averaged only \$5 billion in April 1977, increased more than four-fold to $\$ 23$ billion by 1980 (Greene \#128 October 1984 p. 12).

As the market expanded and as pressures on the dollar intensified, the Desk intervened more forcefully, increasing the size, frequency, and persistence of its operations. The U.S. Treasury began to participate with the System and often announced specific interventions. In addition, the Desk now frequently intervened directly with commercial banks, rather than through a broker (Greene, \#128, October 1984, pp. 12-13). Despite changing tactics, the interventions proved no more successful than in earlier years.

A lack of foreign-currency reserves continued to hinder the Desk's ability to undertake large, sustained, dollar-support operations. At the end of 1977, the combined foreign-currency balances of the Federal Reserve and the Treasury stood at less than $\$ 10$ million equivalent — only enough for a couple of days. In addition, the United States had outstanding foreign-currency obligations, resulting from swap drawings and securities, of roughly \$2 $1 \frac{1}{2}$ billion equivalent (Task Force Paper \#8 pp. 9-10). Since the inception of floating, the United States had financed interventions primarily by borrowing on swap lines, but German authorities grew increasingly reluctant to extend further credits without changes in U.S. macroeconomic policies (Task Force Paper \#8, 16 January 1990, p.10). U.S. monetary authorities decided to acquire a portfolio.

\section{Dollar Free Fall: 30 September - 5 October 1979}

In late 1977, the dollar's depreciation quickened amid persistently high U.S. inflation and reports that OPEC was diversifying out of dollars and into German marks and Swiss francs (FOMC, Transcripts, 18 October 1977, tape 4, p.15). By then, market 
participants believed that the U.S. administration actually favored a dollar depreciation to correct the trade deficit (Greene \#128, October 1984, p.12 - 13, Solomon 1982, pp. 345 46). Although the System had tightened monetary policy somewhat, the real federal funds rate remained near zero, and the System's anti-inflation credibility was quickly eroding. European governments, notably the Swiss and Germans, encouraged the System to intervene more forcefully (FOMC, Minutes, 18 October 1977, tape 4, pp.11 - 12). Although the Desk began to intervene more frequently, at this point its tactics more generally had still not changed: “...the Federal Reserve's approach to the market remained covert and passive: the [Desk] worked through the agent of a different commercial bank each day that placed the Desk's offers of currency into the brokers market, and the amounts offered were no larger than those usually traded in the brokers market.” (Greene \#128 October 1984, p. 17).

The lack of System enthusiasm may have stemmed from Arthur Burns’ growing doubts about the usefulness of intervention. Burns, whose tenure as Chairman was slated to end on 17 January 1978, believed that the dollar's depreciation reflected fundamentals, including the lack of a U.S. energy policy, a stubbornly high rate of U.S. inflation, and the absence of tax incentives for investment. ${ }^{24}$ Without appropriate policy changes, he regarded intervention as futile. While he accepted that, at best, intervention had some "psychological benefits," Burns did not believe that it had permanent effects. He was, nevertheless, willing to intervene "for the sake of better relations with foreign countries," but Burns contended that many foreign governments actually did not favor heavy U.S. intervention, because they could not adequately deal with the excess liquidity that such intervention created in their own markets. For these reasons, he did not want the Desk to "overdo it," and he claimed to have been limiting the amount and frequency of the Desk's activities. $^{25}$

Burns' changing attitude also reflected a deeper, non-economic, concern. He suggested that if the System intervened on a much larger and more persistent scale, the administration and Congress would "indefinitely postpone" more permanent corrective actions (FOMC, Transcripts, 17 January 1978, pp.11). He was referring to budgetary and energy policies. At the 28 February 1978 FOMC meeting, Burns said, "There are differences within the Government about steps that can and should be taken to deal with the dollar problem. The more active our intervention is, the more excuses others within this government have for not taking some of the bridging steps, or some of the more fundamental steps that need to be taken to restore the integrity of the dollar in foreign exchange markets.” (FOMC, Transcripts, 28 February 1978, p. 14) He recommended that the System cut back on the scale of intervention. ${ }^{26}$ In addition, he did not want the Desk to intervene without the Treasury taking a more active role. He seemed to have felt that without additional policy actions, intervention was doomed to failure, and he did not want the Federal Reserve held solely accountable.

Events were already moving in the direction that Burns wanted. Governor Gardner acting on behalf of the FOMC reached an understanding with the U.S. Treasury about intervention. The Treasury, which now felt compelled to express some concern for the dollar, agreed to acknowledge that System operations were undertaken with the close consultation and concurrence of the Treasury. In addition, the ESF would henceforth participate with the System in U.S. operations. Assistant Treasury Secretary Solomon 
and Governor Gardner went to the U.S. Congress and explained that the Treasury would establish a \$1 billion swap line with the Bundesbank for the purpose of intervening (FOMC, Transcripts, 15 January 1978, pp. 2-3). On 4 January 1978, the Treasury and the Federal Reserve announced their intention for joint intervention "to check speculation and reestablish order in the foreign exchange markets.” (Bulletin, January 1978, p. 60). The Treasury publicly announced the existence of its swap line with the Bundesbank, but not its size (Task Force Paper \#9, 24 January 1990, p. 13).

Armed with political cover against failure, the Desk's operations became more forceful and open (see figure 9). Sometimes, the Desk even attempted to achieve a dollar appreciation, instead of moderating the dollar's depreciation. Sometimes the Desk even quoted both bid and offer rates-buying and selling on the same day-to narrow spreads (Green \#128, October 1984. pp. 18 - 22).

Prior to re-activating its swap line, the Treasury had no German mark balances. Over the first four months of 1978, the Treasury drew $\$ 1.0$ billion worth of marks on its swap line with the Bundesbank to finance interventions (see figure 10). On 13 March 1978, the U.S. Treasury also announced that it was prepared to sell $\$ 730$ million of Special Drawing Rights (SDR's ) to Germany and to draw on its reserve position at the International Monetary Fund to acquire additional currencies for intervention (Bulletin, June 1978, p. 449). Between May 1978 and October 1978, the Treasury obtained \$716 million equivalent marks through off-market transactions with central banks, which may have included SDR sales. In addition, the Treasury acquired \$169 million worth of German marks from the Federal Reserve System. The Treasury used these funds, along with some purchases in the market, to repay part of its initial \$1.0 billion swap drawings. Late in the period, however, the Treasury seemed to be in a particularly difficult position. With the dollar still depreciating, it was using funds acquired through swap lines and through off-market transactions with central banks not only to finance further interventions, but also to repay earlier swap drawings. It was often borrowing from Peter to pay Paul.

The System began drawing on its own swap line in October 1977 and by the end of March 1978, the System had drawn \$1.8 billion worth of German marks (see figure 11). On 13 March 1978, the System negotiated a \$2 billion increase in the swap line with the Bundesbank, thereby doubling the facility. Initially, the additional $\$ 2$ billion was not to be continuously available to the System. Once the System repaid amounts drawn on the extended line, the facility was to have reverted to \$2 billion (FOMC, Transcripts, 10 March 1978, pp. 4-5). ${ }^{27}$

Over the one-year period ending on 31 October 1978, the Desk intervened on 97 days, purchasing on average \$55 million worth of German marks on each day (see table 1). This average amount was substantially greater than in previous intervention episodes. Roughly one-third of these purchases were for the Treasury's account. The System also bought other foreign currencies on 30 days. Foreign central banks, notably the Germans, made substantial dollar purchases over this period. The Bundesbank alone bought \$1.1 billion. Despite the heavy intervention, the dollar continued to depreciate, falling $24 \%$ against the German mark and nearly $16 \%$ on a trade-weighted basis. 
During this period, the Japanese asked the United States to intervene against the yen, which was appreciating sharply relative to the dollar (FOMC, Transcripts, 21 March 1978, p. 26). Heretofore, the Desk had never intervened in Japanese yen for the System's account. $^{28}$ The FOMC showed little support for this request in part because intervention against yen would require more resources, but also because trade restraints and other limits to foreign competition in Japanese markets bolstered that country's trade surplus. In addition, the FOMC feared that selling yen would probably result in large losses for the United States since the yen tended to appreciate (FOMC, Transcripts, 18 July 1978, pp. 2-3). (So much for a vote of confidence in sterilized intervention!) Nevertheless, New York Federal Reserve President Volcker and Governor Wallich predicted that such interventions might happen as a concession to the Japanese on some other negotiation, for example, on trade or summit issues (FOMC, Transcripts, 18 July, 1978, p. 3).

Their prediction was accurate. In August 1978, Chairman Miller began talking about activating the Japanese swap line. The Japanese had agreed to a 50-50 risk sharing proposal and reaffirmed their \$2 billion swap limit. The System was still negotiating interest rates on the swaps. By late October 1978, the System was ready. "For some time, the Federal Reserve Bank of New York had been intervening in the New York market for the account of the Japanese authorities. It was agreed that this would continue and that the U.S. authorities would join in this intervention using their own resources.” (Bulletin, March 1979, p. 208).

Despite more forceful tactics in September and October 1978, the dollar's situation only worsened. Underlying the depreciation was a persistent current-account deficit, but more fundamentally, inflation in the United States was rising while inflation abroad had moderated. By mid-October, the depreciation accelerated and, in the Desk's view, overshot a level consistent with fundamentals (Bulletin, March 1979, p. 201). On 24 October 1979, President Carter announced a new anti-inflation program calling for voluntary price and wage guidelines (Bulletin, March 1979, p. 202). Markets were not impressed, and "...the selling of dollars reached near-panic proportions, and dollar rates plummeted to record lows against several major currencies.” (Greene \#128 October 1984, p. 28; see also: Solomon 1982, p. 349).

On 1 November 1978, the administration in conjunction with the Federal Reserve System announced a massive dollar defense package consisting of a 1 percentage point increase in the discount rate to an historic high of $9 \frac{1}{2} \%$, a $\$ 30$ billion increase in foreigncurrency resources, and closer cooperation with Germany, Japan, and Switzerland, whose export-dependent economic growth the dollar's depreciation had crimped. The foreign currency package included a \$7.6 billion increase in the System’s swap lines with these countries. $^{29}$ The Treasury would draw \$3 billion from the U.S. reserve position with the IMF and would sell \$2 billion equivalent SDRs to acquire German marks, Japanese yen, and Swiss francs. The Treasury would also issue up to $\$ 10$ billion in German mark and Swiss franc denominated securities, so-called Carter bonds (Bulletin, December 1978, pp. 940-1) (see figure 12). The Treasury issued Carter bonds in Swiss and German securities markets, rather than to foreign central banks - as was the case with Roosa bonds. Consequently, interventions financed with Carter bonds did not complicate foreign monetary policies by adding liquidity to foreign money markets. Carter bonds automatically sterilized the interventions. 
The temporary, August 1978, increase in the System's swap line with the Bundesbank was now permanent, and the facility had jumped again to \$6 billion-a $\$ 4$ billion increase in less than one year. The System's swap line with Japan increased from \$2 billion to \$5 billion on 1 November 1978, and the swap line with the National Bank of Switzerland increased from $\$ 1.4$ billion to $\$ 4$ billion. This brought the System's entire swap facility to $\$ 29.8$ billion equivalent (see figure 7 ). The System hoped that the increase offered a formidable warning to speculators.

The System quickly drew \$2 billion worth of German marks from the swap line with the Bundesbank and sold nearly all of this in the market. In December, the System drew an additional $\$ 1.4$ billion worth of German marks from the swap line and, again, sold all of these in the market. The Treasury drew $\$ 2.8$ billion from the IMF and $\$ 400$ million on its swap line with the Bundesbank. Most of these funds went initially into the Treasury's foreign-exchange balances, but the ESF quickly sold nearly \$1 billion worth of marks into the market during November. In December, the Treasury drew down its balances and sold an additional $\$ 1.1$ billion equivalent marks. By the end of December, the United States had sold \$5.7 billion worth of German marks. The Treasury accounted for approximately one-third of the total.

The dollar immediately appreciated following the 1 November 1978 announcement, especially against the German mark. Subsequent official interventions in German marks, Japanese yen and Swiss francs were large and coordinated (Bulletin March 1979, p. 202). Over the next two months, the Desk intervened on 28 out of 40 business days (table 1). The median daily sale of German marks was a very large \$144 million equivalent. (The average amount was \$202 million equivalent.) The Desk also intervened on 20 occasions in other foreign currencies, with an average intervention in them equal to $\$ 47$ million. $^{30}$ At the end of December, the dollar was higher than at the beginning of November, a rare outcome for intervention during the early floating era.

The appreciation may have been an initial reaction to the change in intervention policy and to the temporary tightening of U.S. monetary policy. At this time, the real federal funds rate briefly started to rise. Over this period, the Bundesbank acted in concert with the United States, purchasing nearly \$2.8 billion-a very substantial amount. Other central banks also intervened. In addition to signaling cooperation, which may have affected the dollar through an expectations channel, the intervention added to liquidity in European markets.

Federal Reserve Bank of St. Louis President Lawrence K. Roos wondered if the large increase in foreign-currency holdings implied a change in strategy from reacting to disorderly markets to something on the order of pegging. Holmes responded that no one was attempting to peg a rate. He said that the November 1978 program was based on the administration's, the Treasury's, and the Federal Reserve's belief that the dollar had “gone [down] too far.” (FOMC, Transcripts, 17 April 1979, pp. 36-37) This statement suggests, however, that the System and Treasury were not just smoothing a decline in the dollar exchange rate, as had generally been the case in the past. U.S. monetary authorities were now attempting to stop the decline and hopefully reverse it (see also Greene \#128 October 1984, p. 29). 
In early 1979, pressures on the dollar subsided amid some evidence that U. S. policy makers might take inflation more seriously. Those foreign central banks that intervened heavily to defend the dollar, notably the Bundesbank, the Swiss National Bank and the Bank of Japan, used the occasion to drain liquidity (Bulletin, March 1979, p. 202). The dollar strengthened after OPEC announced another oil price hike, because market participants again believed that the United States-like the United Kingdom and Canada - was less vulnerable to oil shocks than many other countries.

With the dollar remaining firm, the System acquired sufficient German marks to repay outstanding swap obligations and to build balances of nearly $\$ 2.4$ billion worth of marks by May 1979. The System purchased most of its German marks off-market from correspondents, but the Desk also bought currencies in the market when the dollar was "particularly strong," suggesting passive intervention designed to stem the dollar's appreciation (Bulletin, September 1979, p. 722).

The Treasury retired its outstanding swap debt with the Bundesbank by March 1979, when marks previously warehoused with the System became available. ${ }^{31}$ The Treasury also acquired German marks through off-market transactions with a foreign central bank. In March 1979, the U.S. Treasury held a portfolio of nearly $\$ 1.2$ billion worth of German marks. The Treasury also held $\$ 1.6$ billion worth of Japanese yen, which it drew from the IMF in November 1978.

The Desk liquidated the System's yen swap debts by February 1979 and shortly acquired a portfolio of \$195 million worth of yen. Throughout 1979, the yen depreciated against the dollar. By May 1979, the U.S. Treasury, the Japanese Ministry of Finance, and the Bank of Japan were encouraging the System to undertake concerted and publicly announced yen purchases. The plan called for the System to accumulate roughly $\$ 800$ million equivalent yen. Yen balances were currently at approximately $\$ 1$ billion equivalent. The Treasury, which already held $\$ 1.6$ billion equivalent yen, would acquire \$200 million yen (FOMC, Minutes, 22 May 1979, p. 41). In November 1979, the Japanese wanted to draw on the swap line, even though they held a very large portfolio of reserves (presumably in dollars). They believed that a drawing would demonstrate U.S. support for their operations (FOMC, Minutes, 20 November 1979, pp. 4-5). The System had initiated a drawing on the yen swap line in November 1978, but no further drawings were ever undertaken. Moreover, the System undertook no additional yen interventions until March 1980.

By late spring 1979, attitudes toward the dollar again started to change. Inflation in the United States exceeded inflation in Germany and continued to rise. Foreign countries were tightening monetary policies faster than in the United States, and interestrate spreads vis à vis short-term mark-denominated assets moved against the dollar (Greene, \#128, October 1984, p. 8 - 10). President Carter's energy speech on 15 July 1979 resulted in further dollar depreciation.

In mid-June, the Desk began forcefully intervening to support the dollar, but the dollar continued to depreciate. In a telephone conference call on 17 July 1979, FOMC participants discussed the merits of intervening relative to the benefits of increasing the federal funds rate. Paul Volcker, President of the Federal Reserve Bank of New York, did not think intervention would work; he favored tightening monetary policy. Volcker 
worried that the "Bundesbank may well get very restive soon about the amounts of liquidity there-we're creating in their markets. I think they've been...quite cooperative up to now but they haven't been doing very much and we're going to be getting into complaints very soon. Gretchen [Margret Greene, Assistant Vice President to the Desk Manager] kind of had some grumbling this morning and it looks like it is pretty big. So I think it is a little bit of an illusion if this continues to think that we can rely on intervention....” (FOMC, Transcripts, 17 July 1979, p.5)

Inflation was rising sharply and the Federal Reserve was rapidly losing credibility across the globe. As Volcker noted, “After years of failed or prematurely truncated efforts to deal with inflation, markets had developed a high degree of cynicism about the willingness of what they dismissed as 'Washington' in general, or the Federal Reserve in particular, to stand firm.” (Volcker and Gyohten 1992, pp. 165 - 166)

The Desk intervened on 44 of the 70 business days between 15 June 1979 and 5 October 1979, selling a massive \$9.1 billion worth of German marks or \$207 million worth of German marks on average each intervention day (table 1). Slightly more than one-half of the transactions were for the Treasury's account. The Desk also sold a small amount of other currencies, but it did not intervene against Japanese yen even though some transaction occurred overnight in the Far East (Bulletin, September 1979, p. 723). The Bundesbank bought \$2.7 billion, on par with its previous purchases.

These interventions against German marks were, on average, the largest to date (table 1). For the first time in the early float period, foreign central banks seemed to be losing confidence in U.S. monetary policy and becoming weary of the domestic liquidity created from buying large amounts of U.S. dollars. Although the Desk was attempting to prevent a further dollar depreciation, the dollar depreciated nearly $8 \%$ against the German mark and $2.5 \%$ on a trade-weighted average basis between 15 June 1979 and 5 October 1979.

Between June and October 1979, the System drew nearly $\$ 4$ billion from its swap line with the Bundesbank and used these funds to finance its interventions. (The System did make small repayments on its swap lines in most months.) The System also drew down $\$ 2.4$ billion from its balances and acquired another $\$ 765$ million worth of German marks from central banks. The Treasury financed one-half of its interventions from marks previously warehoused with the Federal Reserve and 38\% by drawing down its balances of German marks. The Treasury also acquired a small amount of marks through off-market transactions with foreign central banks.

\section{Were U.S. Interventions between 15 September 1977 and 5 October 1979 Successful?}

After September 1977, U.S. interventions became more aggressive than they heretofore had been. The Desk now intervened in substantially larger amounts and much more frequently than it had over the earlier floating-rate period. The Treasury became an active participant in the operations, often announcing major interventions, and the other central banks acted in closer concert with the Desk. In addition, the operations were more visible and, therefore, more consistent with an expectations approach. While the Desk continued to operate frequently through the brokers market, it also began conducting a larger number of transactions directly with commercial banks. The strategy also changed. While the desk often strove to moderate movements in the dollar, it now at 
times attempted to prevent a further depreciation or to achieve a dollar appreciation, or to reinforce the momentum of a dollar rise, or to moderate bid-ask spreads (Greene \#128 October 1984, pp. 19 -20).

Despite the changes in amounts, frequency, objectives, and openness, U.S. operations between 15 September 1977 and 5 October 1979 were no more effective than the U.S. intervention between 2 March 1973 and 14 September 1977. As in the earlier period, they demonstrated some tendency to moderate exchange-rate movements (see table 3).

At times over this period, the Desk sought to foster a dollar appreciation mainly through the sale of German marks. Of the 175 U.S. sales of German marks, however, only 43 (or 25\%) were associated with a same day dollar appreciation against the German mark. Over a period of 537 trading days, we would expect to observe 72 successes purely by chance (see appendix). Because the observed number of successes is more than two standard deviations below the expected, the result suggests that U.S. intervention sales of German marks were a reliable signal that the dollar would depreciate-not appreciate-against the mark. Market participants with information about U.S. intervention-like those banks that often operated on behalf of the Deskcould have profited from selling dollars.

Our analysis of official U.S. purchases of German marks is no different than that for sales. As already noted, however, the Desk typically undertook mark purchases over this period for the purpose of paying down outstanding mark obligations. The Desk undoubtedly timed these purchases to minimize or maximize their impact on the market. Of the 58 purchases of marks, 16 were associated with same-day dollar depreciations. Again, the observed number of successes was more than two standard deviations below the expected number of successes. Market participants that knew of the operations could have profited by selling marks for dollars.

When we evaluate U.S. intervention over this two-year period in terms of moderating the dollar's depreciations or appreciations, the picture is substantially more favorable to the idea that intervention affected the rate. Of the 175 sales of German marks in support of the dollar, 49 (or 28\%) were associated with a slower rate of dollar depreciation on the day of the intervention as compared to the day prior to the intervention. This success count is more than two standard deviations greater than the anticipated number of successes. Of the 58 purchases of German marks 12 (or 20.7\%) were associated with a slower pace of dollar appreciation on the day of the intervention as compared with the previous day. The number of observed successes is also more than two standard deviations larger than the expected number.

When we combine the two criteria into a single criterion-presuming that we do not know which of them the Desk was attempting to achieve on any specific day- the results suggest that intervention had no better than a random impact on exchange-rate movements. Successful U.S. sales of German marks and successful U.S. purchases of German marks fall more than two standard deviations below the expected number. At best only about one-half of the interventions influenced the dollar-mark exchange rate in a manner consistent with the objectives of the U.S. policy makers. 
Over this same period, the Desk sold Japanese yen on 10 days and bought yen on 19 days. This amount seems too few to draw firm conclusions about the effectiveness of intervention against Japanese yen. Nevertheless, in no case is the actual success count statistically greater than the count we would anticipate purely by chance.

By and large over this entire period, the dollar continued to depreciate against the German mark and on a trade-weighted basis. In her detailed analysis of the operations, Greene concluded:

"Evolving U.S. efforts to provide more effective and forceful intervention support for the dollar did, at least in the first instance, help to demonstrate ... that the U.S. government was concerned about the large and rapid decline in the dollar and was willing to try to do something about it. But when intervening actions were not soon followed up with consistent and effective measures to deal with the underlying causes of the dollar's weakness, any positive short-run impact of the intervention faded."

(Green \#128 October 1984, p. 40)

Her conclusion suggests that the Desk viewed the effects of sterilized intervention to be ephemeral.

\section{Monetary-Policy Change}

On 29 September 1979, Paul Volcker, who became the Federal Reserve Chairman on 14 August 1979, went to the IMF/World Bank meeting in Belgrade, where he also conferred with German officials about the dollar's depreciation and the continuing U.S. inflation problem. Helmut Schmidt “...left no doubt that his patience with what he saw as American neglect and irresolution about the dollar had run out.” (Volcker and Gyohten 1992, pp. 165 - 168). ${ }^{33}$ Volcker left the Belgrade meeting early, which raised expectations of a major change in U.S. monetary policy. He set up a special confidential meeting of the FOMC for Saturday, 6 October 1979, ten days ahead of the scheduled meeting.

At the quickly called meeting, the Federal Reserve announced major changes in monetary policy, including a $1 \%$ hike in the discount rate to $12 \%$ and the imposition of an $8 \%$ marginal reserve requirement on increases in managed liabilities. "In addition the System announced that it would place greater emphasis on the supply of bank reserves in its open market procedures and less emphasis on the federal funds rate in seeking to reach its objective for the monetary aggregates.” (Bulletin, December 1979, p. 954). The dollar strengthened immediately following the announced changes in policy.

The policy change, initiated a temporary dollar appreciation. By mid-February, U.S. interest rates were rising faster than foreign interest rates and the dollar moved upward. On 14 March 1980, President Carter authorized the Federal Reserve to impose credit controls (Bulletin, June 1980, p. 456). Concerns about credit controls pushed U.S. rates higher and foreign funds moved into dollars. As the dollar appreciated, foreign central banks began selling dollars to support their currencies (Bulletin, June 1980, p. 455). "By late March [1980], the bidding for dollars had become so generalized that demand pressures, which had previously been concentrated more heavily in markets abroad, began erupting at any time during the 24-hour trading day. To counter disorderly 
conditions, the Desk entered the New York market in March and the first week of April [1980] as a buyer of German marks on 13 occasions, of Swiss francs on 4 occasions, and of Japanese yen on 10 occasions. In early April, the Desk also intervened on one occasion to purchase marks in the Far East.” (Bulletin, June 1980, p. 456). The Desk was, for the first time, actively intervening to limit the dollar's appreciation.

The United States used these funds, along with marks acquired through offmarket transactions with other central banks to liquidate the System's swap obligations with the Bundesbank and to make interest payments on outstanding foreign currencydenominated securities (Bulletin, June 1980, pp. 455-56).

Despite the 6 October 1979 policy changes and the tightening of monetary policy, the nominal federal funds rate fell and the real federal funds rate again turned negative in early 1980. Uncertainty about Volcker's prospects for reducing inflation and keeping it low with the economy now in recession and the unemployment rate rising sharply probably explains the dollar's 12\% depreciation between 8 April 1980 and 11 July 1980. In response, the United States intervened. The Desk sold German marks, but it also sold French francs to avoid aggravating the weakness of the mark relative to the franc in the EMS (Bulletin June 1980, p. 456). The System sold \$159.6 million worth of French francs, which it financed by drawing on its swap line with the Bank of France. The System continued with large periodic interventions through mid-July.

The Desk intervened, buying an average of \$121 million worth of German marks on each of 26 days during the 68-day period (table 1, figure 9). The average size of a transaction was smaller than in the previous two intervention episodes. On 11 days the Desk bought other foreign currencies, mostly French francs (\$160 million) and Swiss francs ( $\$ 144$ million). Despite the intervention, the dollar depreciated nearly 12\% against the German mark and $10 \%$ on a trade-weighted basis.

\section{Were Interventions between 8 October 1979 and 17 April 1981 Successful?}

Despite the change in U.S. monetary policy, the success of the U.S. intervention operations between 8 October 1979 and 17 April 1981 was similar to that in earlier periods (see table 4). Of the 55 sales of German marks, only 15 (27.3\%) were associated with a dollar appreciation, well below the expected number. Again, U.S. intervention sales of German marks provided a reliable signal that the dollar would depreciate. Seventeen of these mark sales, however, were associated with a slower pace of dollar depreciation on the day of intervention than on the previous day, suggesting some tendency to dampen dollar depreciations. When we combine the two criteria into a single criterion-presuming that we do not know which criterion the Desk was attempting to achieve on any given day - the number of successes was no better than random.

Between 8 October 1979 and 17 April 1981, the Desk bought German marks on 114 days. As noted, sometimes the Desk actively sought to slow the dollar's appreciation, but on most occasions the Desk only wanted to acquire German marks to pay off debts and to accumulate a portfolio of German marks. (We discuss the acquisition of a portfolio in the next section.) Even when the Desk bought German marks to pay down debts or to acquire a portfolio, it conducted passive interventions. Of these 114 purchases of German marks, 41 (36\%) were associated with a same-day dollar depreciation. This number was substantially fewer than we would randomly anticipate. 
Twenty-five of these 114 purchases of German marks, not untypically, were associated with a smaller same-day dollar appreciation relative to the previous day. This amount was greater than anticipated and suggests some capacity to slow the pace of a dollar appreciation. When we combine the success criteria, however, the count was no better than random.

Over this same period the United States bought Japanese yen on 10 occasions and sold Japanese yen on only one day. While the number of interventions was too small to draw strong conclusions, the success counts were never better than the number that we would randomly anticipate given the variable nature of day-to-day exchange-rate movements.

\section{Foreign Currency Debt and the Decision to Increase the U.S. Portfolio ${ }^{34}$}

Between 1973 and 1977, the System never held more than \$170.6 million worth of foreign exchange and never more than \$51.6 million worth of German marks, its main intervention currency (figure 5). ${ }^{35}$ These amounts were generally smaller than the amounts that the System held between 1962 and 1972. Moreover, between 1973 and 1977, the Treasury held virtually no balances of foreign exchange (figure 6). In large part this aversion to balances reflected the U.S. view-a remnant of the Bretton Woods period - that foreign central banks would undertake most of the intervention (Axilrod and Holmes, 10 April 1979, p. 1). Consistent with this view, between 1973 and 1977, the United States accounted for only about $5 \%$ of the total exchange-market intervention that the major central banks undertook against the dollar (Morton and Truman, 10 April 1979, p. 3).

This lack of ready reserves forced the United States to rely heavily on borrowed funds to finance its interventions during the early dollar float. As we have shown, in order to meet their subsequent debt obligations, both the System and the Treasury needed to expeditiously buy back the foreign exchange that they previously sold. As noted, the Desk often timed these buy backs to have the best possible effect on the market.

In early 1979, the FOMC considered increasing the System's portfolio of foreign exchange reserves. ${ }^{36}$ The key reason for doing so was to avoid the growing conditions that countries_-notably Germany-were attaching to swap drawings (Task Force Paper \#8, 1990, p. 11). As the amount and persistence of U.S. interventions increased in late 1977, so did the debt obligations of the United States. At the end of 1978, for example, the System had a record $\$ 5.5$ billion in outstanding swap obligations, and the Treasury had $\$ 890$ million in swap obligations and nearly $\$ 2.2$ billion in outstanding Carter bonds (Task Force Paper \#8, 1990, table IV.b.). Any foreign-imposed conditions could limit the United States’ ability to conduct future interventions quickly and efficiently.

In part, countries increasingly imposed conditions on borrowing because the nature of intervention and the risks associated with repayment had changed. Under Bretton Woods, countries presumably borrowed to finance temporary balance-ofpayments shortfalls not reflecting fundamentals. Monetary authorities viewed such debts as largely self-liquidating and easily repayable when financial funds flowed back into the borrowing country (see chapter 4). Now, however, with intervention becoming larger, more persistent, and aimed at smoothing longer-term movement in exchange rates, rather than financing temporary and reversible balance-of-payments problems, the previous 
conceptualization of self-liquidating debt was no longer valid. Confidence in countries' ability to quickly repay their debts had ebbed (FOMC, Transcripts, 20 April 1976, tape 1, p. 6). The United States itself had occasionally placed conditions on the swap drawings of other countries to insure their timely repayment. In 1976, for example, the United States conditioned a swap loan to Britain, requiring that country to subsequently obtain foreign exchange from the International Monetary Fund (Bulletin, December 1976, p. 1005).

The conditions that countries-notably Germany-were placing on the United States, however, had more to do with a pessimism about U.S. monetary policy than about the country's ability to repay. Prolonged interventions, after all, were a symptom of a U.S. policy failure, and Germany, which was reducing its inflation at the time, wished to limit the spillover effects. As Holmes and Pardee (10 April 1979, p.4) explained: "[In 1978,] the Bundesbank went so far as to limit our use of the swap lines because of its concern that the marks so created would contribute to a potentially inflationary expansion of the monetary base in Germany." If Germany and other countries limited quick access to borrowed funds, the United States needed a larger portfolio of foreign exchange to pursue a strategy of smoothing longer-term movements in the dollar (Axilrod and Holmes, 10 April 1979, p.1). ${ }^{37}$

Another important motive for increasing the portfolio centered on the System's relationship to the U.S. Treasury concerning intervention. From 1973 through 1977, the Treasury rarely intervened; it essentially continued its traditional role of promising to backstop the System's swap borrowings. The System had essentially free reign in running U.S. intervention policy. In November 1978, the Treasury expanded its role in terms of both its overall resources and its willingness to engage in day-to-day operations. By 1979, the Treasury had a substantial portfolio of foreign exchange. The Treasury held \$3.4 billion worth of German marks, \$1.2 billion worth of Swiss francs, and \$1.4 billion worth of Japanese yen, and it had an additional \$3.3 billion in German marks and Swiss francs warehoused with the Federal Reserve System (Axilrod and Pardee, 10 April 1979). ${ }^{38}$

The System's staff worried that if U.S. interventions increased in size and frequency, and if the Treasury's portfolio of foreign exchange continued to expand relative to the System's, the FOMC would lose its influence over U.S. intervention policies. Although the Treasury had relinquished much of its authority to the System in recent years, it continued to have primary responsibility over exchange-rate policies. While the System had legal authority for its own intervention, its exact role vis-à-vis the Treasury remained ambiguous but clearly secondary (see chapter 4). Beyond its technical expertise, the System acquired much of its authority through the resources that it brought to the venture. Now its relative influence seemed threatened.

The FOMC also worried about Congress's response to the acquisition of foreign exchange. In 1979, Congress did not seem to favor the accumulation of additional reserves (Morton and Truman, 10 April 1979, p. 7). Many of the FOMC's concerns mirrored those that it faced when it initially began intervening in 1962 (see chapter 4). Some FOMC members wanted clear Congressional and Treasury approval before the System acquired a larger portfolio and a greater exposure to foreign-exchange risk (see FOMC, Transcripts, 17 April 1979, 35-45). 
Holmes and Pardee (10 April 1979, p. 9) suggested that, "A good cushion to begin with would be 2 to 3 days worth of heavy intervention." That seemed to translate into $\$ 1$ billion worth of German marks, $\$ 400$ million worth of Swiss francs, and $\$ 300$ million worth of Japanese yen. These were the key international currencies, and the staff thought that their dollar exchange rates had wider effects on markets and sentiments than other currencies' dollar exchange rates. In addition, the staff recommended \$100 million worth of (each) French francs, Netherlands guilders, and Belgian francs (Holmes and Pardee, 10 April 1979, p. 9). These amounts would increase the System's informal limits on currencies from $\$ 500$ million equivalent to $\$ 2$ billion equivalent.

As the dollar began to stabilize in 1979, the System and the Treasury began to acquire foreign currencies, but they needed these funds initially to pay down outstanding debts rather than build reserve balances. At the end of 1979, the United States had, on net, outstanding foreign currency obligations totaling nearly \$2.9 billion equivalent, mostly in German marks. The Federal Reserve held nearly $\$ 2.4$ billion in foreign currency balances, but had $\$ 3.2$ billion in outstanding swap debts. The Treasury held nearly $\$ 5.3$ billion in foreign currency balances, including $\$ 2.1$ billion equivalent German marks and Swiss francs warehoused with the Federal Reserve System. Against these assets, the Treasury had nearly equivalent amounts of outstanding Carter bonds. ${ }^{39}$ U.S. monetary authorities had maintained a negative net open position in foreign currencies (net liabilities) in nearly every year since interventions began in 1962 (Task Force Paper \#8, January 1990, table I). ${ }^{40}$

After October 1979, as the dollar appeared to bottom out, and especially after September 1980 as the dollar began a sustained appreciation, the Desk took advantage of opportunities to buy foreign currency and pay down outstanding debts. Because the Desk remained concerned about sparking another dollar depreciation through its foreign currency purchases, it operated on both sides of the market. The Desk bought foreign currency when conditions permitted (passively intervened) and actively intervened when markets were disorderly. ${ }^{41}$ It did so in close proximity, even during the same day: "On several occasions, operations of both types were conducted at different times or in different markets within a day.” (Greene \#129, August 1984, p. 12)

The Desk also began considering commercial bank offers to sell foreign exchange directly to the United States. "In general, banks came to the Desk with offers to sell currencies when there were few other buyers — such as when the dollar was moving up sharply or after the bulk of trading had subsided for the day-or when they had an order they felt was too large for the market to absorb.” (Greene \#129 August 1984, p.12) ${ }^{42}$

The United States also acquired foreign exchange to pay down its debt from foreign central banks, especially the Bundesbank. The Bundesbank sold the Desk marks off market and also acted as its agent in the Frankfurt market. The Desk also operated in the Far East (Greene \#129 August 1984, p.13-14)

The U.S. strategy was to pay down short-term debts - swap lines-before paying off longer-term obligations, like Carter bonds. Since all of the System's debts were short term, the System paid them off by 15 October 1980. The Treasury was debt free by 5 December 1980 (Task Force Paper \#8, p. 11-12). 
After paying down or covering their obligations, the System and the Treasury continued to take advantage of the dollar's appreciation and to acquire foreign currencies. By the end of 1980, the United States held a positive net open position of \$2.5 billion equivalent, its first since 1962. When these operations ended in February 1981, the System held approximately $\$ 4.5$ billion in German marks and roughly another $\$ 1$ billion in other currencies. The Treasury held $\$ 3.5$ billion in German marks and roughly $\$ 2$ billion in other currencies [Task Force Paper \#8, 1990, 12 and Tables II.b. and II.c.]. At the end of 1981, the United States held a net open position equivalent to \$6.8 billion.

Technically, acquiring such a portfolio was not very difficult, but investing it in earning assets posed problems for the System. Prior to 1980, the System did not have very good options for investing its foreign-currency balances. The Federal Reserve Act did not allow the System to invest in foreign government securities; it only allowed the System to place funds in interest-bearing deposits with other central banks and in bills of exchange. Holmes claimed, however, that the System lacked authority to invest in foreign government securities only because few such securities existed in 1914. The Federal Reserve Act listed things in which the System could invest and if government securities existed, he claimed, they would have been included. Holmes offered that government securities were not "prohibited;" they just were not "listed." (FOMC Transcripts, 17 April 1979, 38-39].

Because of the legal restrictions against holding foreign government securities, the System invested currency balances in deposit accounts at central banks or with the Bank for International Settlements prior to $1980 .{ }^{43}$ If a central bank paid interest on System deposits, they based the rate on a non-market rate, such as the bank's discount rate. Sometimes the funds simply earned no interest. The System often placed funds with the BIS to gain interest earnings if a central bank paid none or to accommodate foreign central banks' desire to keep funds in the market for monetary-policy considerations (Task Force Paper \#8, 1990, pp. 17-18).

As suggested, some central banks-notably the Bundesbank, whose currency constituted the bulk of the System's foreign-exchange holdings - were not legally allowed to pay interest on deposits or even to offer the System deposits. To earn a return on U.S. holdings of German marks, the United States established a double-forward facility with the Bundesbank in 1978. Accordingly, the United States sold its mark holdings forward to the Bundesbank and simultaneously bought the marks back forward with the exchange rates structured to yield the United States a return. The instruments typically matured in three months. The Treasury also placed mark balances acquired through the sale of Carter bonds in securities that the German Finance Ministry issued. These had limited transferability and marketability (Task Force Paper \#8, 1990, pp. 1819).

The Monetary Control Act of 1980 allowed the System to invest foreign currency balances in securities that foreign governments issued or guaranteed (Task Force Paper \#8, p. 13). This allowed the Federal Reserve to invest in an array of instruments, some more liquid than others. 


\section{Warehousing}

Warehousing refers to a foreign-currency swap between the Federal Reserve System and the U.S. Treasury that gives the Exchange Stabilization Fund temporary access to dollars. In a typical warehousing transaction, the Exchange Stabilization Fund sells foreign currencies spot to the Federal Reserve and simultaneously buys them back for delivery at a specific future date, generally within one year. Because both the spot and forward legs of the swap occur at the same exchange rate, neither party incurs foreign-exchange risk from warehousing, but the foreign currency can still sustain valuation gains or losses vis à vis the market, which then fall to the ESF. The Federal Reserve places the foreign exchange that it warehouses into an appropriate interest earning instrument and derives a return over the interim of the operation, while the ESF has use of the dollars so acquired. Warehousing typically has occurred at the Treasury's initiative, but unlike with the monetization of gold or SDRs, the System is not obliged to warehouse funds for the Treasury. The FOMC must give its approval to the operations and annually sets an overall authorization for warehousing.

As with any foreign-exchange operation, the Federal Reserve stands ready to offset unwanted changes in bank reserves that may result from warehousing. Should the ESF subsequently buy foreign exchange with its newly acquired dollars, the System will drain any unwanted increase in dollars reserves. Often, however, the ESF will not immediately purchase additional foreign exchange and instead will temporarily "lend" the funds to the Treasury by acquiring a Treasury security. In this case, the Treasury's account at the Federal Reserve Bank of New York increases. If the Treasury subsequently draws down this account, the System can easily sterilize the resulting increase in bank reserves. Likewise, the System will sterilize any unwanted drain on bank reserves that might arise when the ESF repays its warehousing obligation to the Federal Reserve System.

Over the years, warehousing-type transactions have served four functions. In the main, warehousing has temporarily augmented the limited dollar resources of the Exchange Stabilization Fund. As explained in chapter three, the ESF has financed its foreign-exchange operations over the years from an initial Congressional appropriation and from the periodic monetization of SDRs, which the ESF acquired either through IMF allocations or from other countries (Schwartz 1997). Initially, however, warehousinglike operations served a second purpose. As detailed below, they provided the Treasury with a means of covering its foreign-currency exposure on outstanding debt obligations that did not entail selling foreign exchange to the System and thereby shifting that exposure to the Federal Reserve. On at least one occasion, the Federal Reserve acquired needed foreign exchange on a swap basis from the ESF; the System initiated the warehousing operation. Lastly, warehousing may have occasionally provided the U.S. Treasury with a means of acquiring temporary dollar funding that avoided the federal debt limit. When the ESF parks the dollars that it has acquired through warehousing in U.S. Treasury securities, the Treasury can reduce the amount of debt that it sells to the public and the amount of debt subject to the Congressional debt ceiling (Stevens 1989). 


\section{The Evolution of Warehousing}

In 1963, the FOMC gave the Desk authority to buy foreign exchange in the market and to sell it to the Treasury as cover for outstanding foreign-exchange obligations. This authorization became the basis for future warehousing. At the end of 1963, the Treasury had outstanding lira securities amounting to nearly $\$ 200$ million equivalent and wanted to cover its exposure by buying lira, but the Treasury lacked sufficient resources to do so. At the time, the lira was trading somewhat below par, making lira purchases especially propitious (FOMC Minutes 12 November 1963, pp. 110). Charles Coombs, Special Desk Manager, recommended that the Federal Reserve System acquire Italian lira spot and sell it forward to the Treasury. The forward sale eliminated the System's lira exposure. Coombs sought authority for \$100 million equivalent.

Coombs viewed the current situation as a "rather special one" and sought authorization only for lira. The Treasury had outstanding debt obligations in other currencies, and Coombs assumed that he could seek further specific authorization should the need arise. The President of the Federal Reserve Bank of Boston, George H. Ellis, however, thought that a routine facility would help in redeeming Treasury foreigncurrency securities and might also make them more saleable (FOMC Minutes 12 November 1963, p. 7). The resulting foreign currency directive stated:

"The Federal Reserve Bank of New York is also authorized and directed to make purchases through spot transactions, including purchases from the U.S. Stabilization Fund, and concurrent sales through forward transactions to the U.S. Stabilization Fund, of any of the foregoing [authorized] currencies in which the U.S. Treasury has outstanding indebtedness, in accordance with the Guidelines and up to a total of $\$ 100$ million equivalent. Purchases may be at rates above par, and both purchases and sales are to be made at the same rate.”

(FOMC Minutes 12 November 1963, p. 10) (emphasis added)

In allowing the System to buy foreign exchange spot from the ESF and sell it back forward to the ESF, the directive authorized warehousing. The FOMC Minutes, however, do not reveal how the insertion of the critical phrase: "including purchases from the U.S. Stabilization Fund" came about.

The mechanism of these initial lira purchases, of course, did not conform to a warehousing operation as it would eventually be understood. In January and March 1964, the Desk purchased $\$ 83$ million lira spot from a foreign central bank and sold it forward to the Treasury. The authorization also constrained the operations by specifying that warehousing transactions be limited to currencies in which the Treasury had an outstanding indebtedness.

In March and April 1966, the Desk used such operations to provide cover against the Treasury's Swiss franc and German mark obligations and quickly began running out of authority. Coombs proposed an increase to $\$ 150$ million for such operations, but “... some members suggested that the limit might be removed entirely, or set at a level 
considerably higher than Mr. Coombs proposed, since the operations under discussion were riskless and helpful to the Treasury.” (FOMC Minutes 12 April 1966, pp. 6-7) The Committee authorized \$200 million, but the actual amount of marks and francs held under this authority never exceeded \$75 million equivalent (Morton, 14 January 1977, p. 1) (see figure 13).

In July and August 1966, the System also sold over \$100 million British pounds on a "swap basis" to the U.S. Treasury-essentially warehousing in reverse. One of these transactions was for a single day, designed to reduce System balances on a statement day, while the other extended until January $1967 .{ }^{44}$ These were not to cover Treasury debt obligations, and hence, not subject to the November 1963 authorization. The System, however, had frequently transacted in foreign exchange on a spot and forward basis even prior to the 1963 authorization. The reason for the November 1963 authorization was that covering the Treasury's outstanding debt had little to do directly with exchange-market stabilization and hence required a separate FOMC authorization.

In November 1967, as part of an international aid package for Britain, the United States agreed to acquire \$500 million in "guaranteed sterling." Afraid that the transaction would leave the ESF cash strapped and hoping to give the System a bigger stake in the associated policy decisions, Coombs recommended that the System warehouse-in the traditional sense-an additional \$150 million in guaranteed sterling for the ESF. ${ }^{45}$ The System had authority to warehouse up to $\$ 200$ million in currencies for which the Treasury had an outstanding indebtedness, but the Treasury did not have an outstanding indebtedness in British pounds. Hence, in addition to increasing the warehousing authority to $\$ 350$ million, Coombs also asked the FOMC to delete the provision in the authorization that restricted warehousing to currencies in which the Treasury had outstanding indebtedness (FOMC Minutes 14 November 1967, pp. 18 -19).

The System's share of the aid package to Britain was $\$ 100$ million. Coombs thought that he could explain the System's holding of this amount as necessary to meet its "needs for market operations." In fact, however, the United States was attempting to prevent a devaluation of the pound, not defend the dollar, and policymakers viewed the \$500 million as an extended credit. The Federal Reserve Act justified foreign-exchange operations "undertaken to deal with such problems as short-run disturbances in the foreign exchange market. An extension of longer-term credit by the System to the Bank of England - even if ultimately for the purpose of safeguarding the value of the dollarwas of a character quite different from open-market operations.” (FOMC Minutes 14 November 1967, p. 34) Warehousing an additional \$150 million worth of British pounds for the Treasury allowed the System to help extend credits to the Bank of England without appearing to violate its mandate for intervention and, perhaps more importantly, gave the System more weight in the policy decision.

The FOMC raised the authorization to \$350 million at its November meeting, but the System did not undertake any warehousing until June 1968. Then it warehoused \$200 million worth of guaranteed sterling for the Treasury until August 1968. In September 1968, the FOMC raised the authorization for warehousing to \$1 billion to facilitate further credits to Britain (Morton 1977, p.2). The Treasury, however, did not ask to re-use the facility, and the System warehoused no foreign exchange until May 1969. 
Implicit in the November 1967 authorization was an understanding that the \$150 million increase in the overall authorization pertained only to British pounds and that the System could only warehouse \$200 million — the April 1966 limit—in other currencies. In mid-1969, the Treasury expected France to sell it gold. While the Treasury could monetize gold with the Federal Reserve to pay for the transaction, it preferred to wait, because the Treasury expected the IMF to exercise an outstanding claim on the U.S. gold stock. Instead, the Treasury hoped to bridge the two possible gold transactions by warehousing foreign currencies with the System. In June 1969, the FOMC agreed to liberalize the "informal understanding governing use of the existing authority to warehouse" so that the ESF could use the entire facility for general purposes. The need, however, did not materialize until December 1969 when the System warehoused francs and lira.

Beginning in May 1969, the System began warehousing British pounds for the ESF. By August, the System held \$300 million equivalent. The ESF had also undertaken a series of gold purchases that depleted its funds. By year's end, following an additional \$500 million gold purchase, the System’s warehousing operations reached \$975 million, and in early January they briefly hit the $\$ 1$ billion limit. At that point the System had warehoused \$675 million in British pounds, \$200 million worth of French francs and \$125 million equivalent Italian lira. The Treasury subsequently monetized \$1 billion of gold and paid off its warehousing obligations to the System.

After this, the warehousing facility remained dormant for the next eight years, except for one warehousing-like transaction that the System initiated. In July 1972, the System intervened in the foreign exchange market against German marks. At the time, the System held very few German marks, and the Treasury had suspended the swap lines. To finance its intervention, the System bought $\$ 2.5$ million worth of marks on a swap basis from the U.S. Treasury and sold them back forward—a System-initiated warehousing operation.

On 17 January 1977, at the request of Treasury Secretary William Simon, the FOMC raised the warehousing authorization to $\$ 1.5$ billion, and agreed to warehouse up to one-half of this amount for twelve months and the remainder for six months. The FOMC allowed the more generous warehousing authorization to help finance the Treasury's participation in another credit facility for the Bank of England, but the Treasury never drew on the line. ${ }^{46}$

On 14 December 1978, the FOMC again altered its authorization, increasing the limit to $\$ 1.75$ billion and now allowing the System to warehouse foreign currencies directly with the U.S. Treasury as well as the ESF. ${ }^{47}$ The Committee took this action in conjunction with the 1 November 1978 dollar support program, which we previously discussed. The System was a strong advocate of a large, active dollar-support program and viewed warehousing as a necessary contribution to the operation. Five days later, the Committee raised its warehousing limit to $\$ 5$ billion with a standard twelve-month term. This would allow the Treasury to exchange foreign currencies acquired through the issuance of Carter bonds with the System for dollars. The Treasury issued nearly \$1.6 billion German-mark-denominated bonds in December 1978 and immediately warehoused almost that entire amount. ${ }^{48}$ The Treasury also issued $\$ 1.4$ billion in Swiss franc Carter bonds in January 1979 and, likewise, warehoused nearly all of the proceeds 
with the System. By May 1979, the System had warehoused nearly \$3.5 billion for the Treasury, and by June 1981, the Treasury had warehoused $\$ 4.2$ billion with the System. The System continued to warehouse these currencies for the Treasury through mid-1983 (see figure 13).

\section{Financing Public Debt}

An important aspect of warehousing is that it provided the Treasury with funds that were not subject to the Congressional limits on public debt. If the ESF did not immediately use the dollar proceeds from a warehousing operation to purchase foreign exchange, it would place those funds in Treasury securities. As a consequence, the Treasury needed to issue less debt to the public — debt subject to a statutory limit. The Federal Reserve had no control over how the Treasury or the ESF used the dollar funds that it acquired through warehousing, but clearly understood the issue at hand.

In late January 1969, Holmes suggested warehousing foreign exchange for the Treasury as a way to help the Treasury avoid breaching the statutory debt ceiling. At the time, the Treasury simply needed cash: “The Treasury's current problem," according to Holmes, "is not related in any way to current developments in the international situation." (Hackley 31 January 1969, pp. 2-3)

Board of Governors General Counsel Howard Hackley pointed out that the Federal Reserve had legal authority to warehouse since purchases of foreign exchange from the Treasury were tantamount to open-market operations and that the System had no control over how the Treasury used the dollar funds: “... the fact that their purpose may appear to be solely to provide the Treasury with additional cash does not affect their legality.” (Hackley 31 January 1969, p. 3) Hackley cautioned, however, that open market operations should be used "to accommodate commerce and business with regard to their bearing on the general credit situation.” (Hackley 31 January 1969, p. 3). At that time, General Counsel Hackley suggested that such a use of warehousing would be legally acceptable, because to do otherwise might affect the general credit situation of the country and the value of the dollar. This was particularly likely, Hackely reasoned, if the Treasury otherwise sought cash by selling off a substantial part of its foreign-exchange portfolio (Hackley 31 January 1969, pp. 3-4).

Hackley, however, understood the precarious position that using warehousing to avoid the debt limit could pose for the System:

It must be recognized that adoption of the proposed arrangement could subject the System to criticism. It might be charged, for example, that the proposed warehousing transaction would constitute a direct extension of credit to the Treasury by the Federal Reserve and would be contrary to the spirit if not the letter of the law, particularly in view of the express provisions contained in section 14(b) of the Federal Reserve Act for direct borrowing by the Treasury from the Federal Reserve within prescribed statutory limits. However ... I believe that the transactions would be legally defensible as not being designed primarily to aid the Treasury but 
as intended to avoid developments that would have an adverse impact upon the 'credit situation of the country."”

$$
\text { (Hackley } 31 \text { January 1969, pp. 4-5) }
$$

At the time, the System did not warehouse any foreign exchange for the Treasury until the British pound support program in May 1969. An improvement in the Treasury's cash flow relieved the immediate debt-limit problem (FOMC Minutes, 4 February 1969, p.16). Still the System understood that warehousing financed Treasury expenditures: "During the six-month period [August 1978 to January 1979], the Federal Reserve 'warehoused' foreign currencies by taking foreign exchange acquired by the Treasury that was not immediately needed to finance foreign exchange intervention in return for dollars that were needed by the Treasury in its own domestic operations." (emphasis added) (Bulletin, March 1979, p. 219). Congress raised the U.S. statutory debt limit in August 1978. By December, outstanding eligible debt was rapidly approaching the new limit. All else constant, the Treasury would have breached the debt limit in March 1979 had it not warehoused funds with the System.

The situation became more problematic for the System after December 1978, when the FOMC extended warehousing directly to the Treasury-as opposed to only the ESF. The former was less defensible than the latter. Volcker seemed to appreciate the distinction: "[warehousing] could be construed as a form of Treasury borrowing from the Federal Reserve which isn't covered by the other prohibitions on their borrowing [the debt limit]. We need the justification that it is the Exchange Stabilization Fund's lack of assets, not a general lack of funds on the part of the Treasury, that gives rise to this [warehousing]" (FOMC Transcripts 18-19 December 1980, p. 26). The System did not want to appear to finance Treasury borrowing in breach of the appropriations process and Congressional limits on public debt.

As explained in chapter six, authorization for warehousing would eventually reach $\$ 20$ billion. The parallels between warehousing foreign exchange for the ESF and lending directly to the Treasury, in conjunction with concerns about the System's independence, would be a key factor in eventually terminating U.S. intervention.

\section{A Minimalist Approach.}

By late February 1981, as the dollar continued to appreciate, the United States had effectively stopped intervening. ${ }^{49}$ On 17 April 1981, Treasury Secretary Donald Regan announced that henceforth the United States would follow a minimalist strategy with respect to intervention. Over the next four years, the United States rarely intervened in the foreign-exchange market.

Under Secretary of the Treasury for Monetary Affairs, Beryl Sprinkel, the architect of the policy change, explained the Treasury's reasons to the U.S. Congress Joint Economic Committee on 4 May 1981 (see Sprinkel, Testimony, 1981.). His analysis of intervention was strikingly modern. Sprinkel understood that the dollar's depreciation since 1973 mainly reflected the rising U.S. inflation rate, and he noted that the United States primarily intervened to slow the rate of the dollar's depreciation. The U.S. inflation rate had exceeded the German inflation rate consistently since 1974 . This type of intervention-particularly the heavy interventions after 1978-did not address the 
fundamental underlying economic problem; it only "treated the symptoms." Sprinkel pointed out that sterilized intervention did not affect the macroeconomic determinants of exchange rates. He suggested that in such cases intervention "merely encourages disarray in the exchange market” (see Sprinkel, Testimony, 1981, p. 12-13).

Sprinkel did not deny that exchange markets occasionally became disorderly, but he believed that the exchange market had evolved over the years of generalized floating and had become "more efficient in evaluating and adjusting to new information." As this observation suggests, he viewed intervention as potentially operating through a broad expectations (or signaling) channel—a more modern version of the Desk's "psychological" effect-and he took this interpretation to its logical, and uncomfortable, conclusion: "Significant and frequent intervention by governments assumes that relatively few officials know better where exchange rates should (or shouldn't) be than a larger number of decision makers in the market, and that public funds should be put at risk on the basis of that assumption.” (Sprinkel, Testimony, 1981, p. 13)

The Under Secretary also suggested that heavy, persistent intervention could make it "more difficult to follow the correct domestic monetary policy." (Sprinkel, Testimony, 1981, p. 13). He did not elaborate, but since 1979, the Desk had been acquiring foreign exchange-selling dollars-while the FOMC was attempting to tighten monetary policy. The System sterilized this intervention, but such contradictory activities complicates policy making and, if observed by the markets, must weaken central-bank credibility. This exact issue would arise again in the late 1980s and early 1990s and would prove the key reason for ending the United States' long involvement in intervention.

\section{Conclusion}

From the inception of generalized floating through the middle of 1980, the dollar depreciated 54\% against the German mark, the key target of U.S. interventions over this period. The dollar's depreciation was a symptom of the Great Inflation, which chiefly resulted from a policy framework that downplayed the role of money in the inflation process and from a policy preference for low unemployment over low inflation. During almost all of this time, the real federal funds rate was either negative or close to zero, and inflation in the United States exceeded inflation in Germany, often by a substantial margin. By 1977, confidence in the FOMC's ability and willingness to subdue inflation was rapidly evaporating. The dollar's depreciation quickened and did not reverse until mid-1980, after the FOMC substantially changed its monetary-policy approach and demonstrated a willingness to maintain a disinflationary stance despite severe economic weakness.

As one might expect in an inflation-charged atmosphere, U.S. foreign-exchange interventions over this period were largely ineffectual in halting the dollar's decline. Overall, private market participants could have made money by following the adage at the beginning of this chapter and betting against the Desk's operations. Still, on 25\% of the days over which the Desk sold German marks, the dollar experienced a smaller depreciation than on the previous day. This percentage is greater than we would anticipate given the random nature of day-to-day exchange-rate movements, and it suggests that the Desk had a limited short-term capacity to lean against the wind. This 
narrow competency, however, could not quell a growing skepticism about the operations' effectiveness, which led to their termination in early 1981.

Besides inflation, the absence of a clear theoretical framework surely hampered the operations. Such a framework never guided the Desk's actions. The Desk claimed a general "psychological effect," but their interventions — covert, and small—were wholly inconsistent with the view that officials might provide the market with information useful for price discovery. Quite the contrary, a fear that the market might learn about an intervention, bet against it, or totally overwhelm it, drove the Desk's operations, at least through 1977. Instead of providing new information to the market, the Desk attempted to trick those market participants who were selling dollars into thinking that a market-based force was emerging to buy dollars. The Desk's operations also seemed out of sync with academic thinking. At the time, most economists, including the Board's research staff, viewed intervention as operating through a portfolio-balance mechanism. A policy of borrowing foreign exchange to finance relatively small dollar support operations, but then quickly reversing course to repay the loans, would not have a significant lasting effect on the outstanding stock of dollar-, and mark-denominated assets nor on risk premia. Hence, the operations could not affect exchange rates through a portfolio-balance channel. At best the operations may have had an occasional temporary effect by creating unwanted liquidity in German money markets, but the Bundesbank, like the Federal Reserve System, was attempting to reduce inflation. For that reason, Germany grew increasingly reluctant to fund dollar support operations through swap lines. 
Figure 1: U.S. Great Inflation

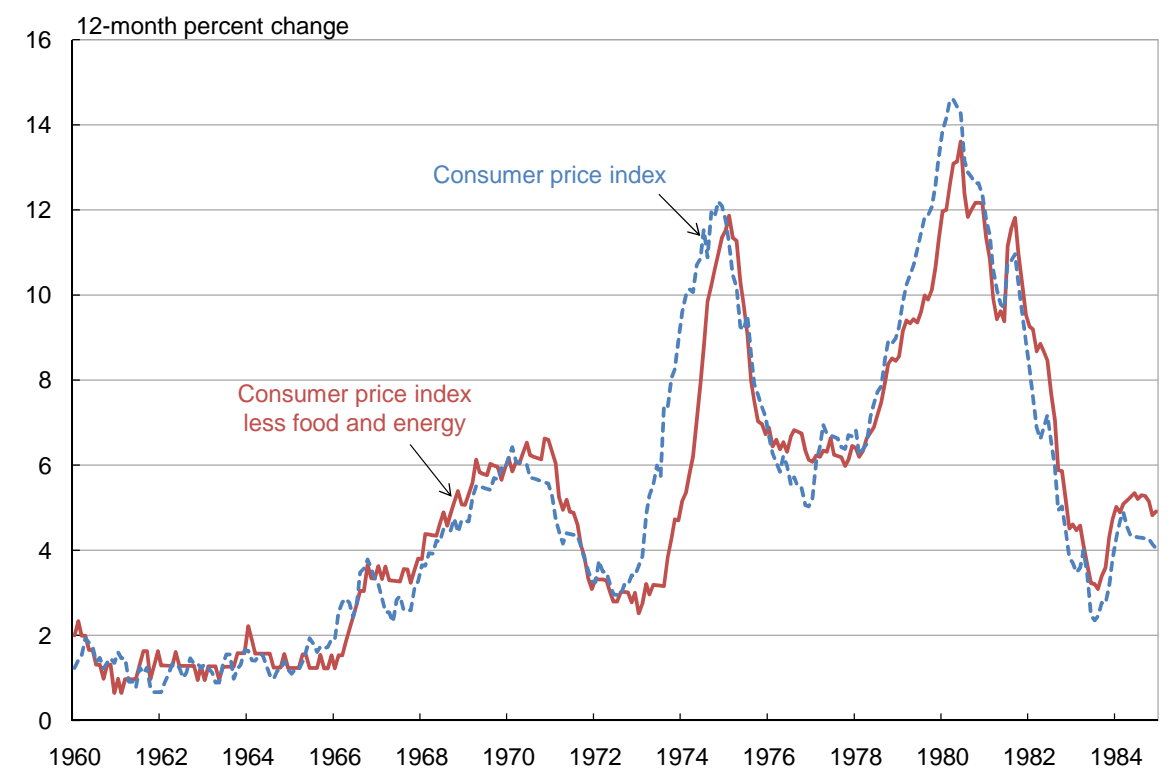

Source: Bureau of Labor Statistics

Figure 2: Real Federal Funds Rate

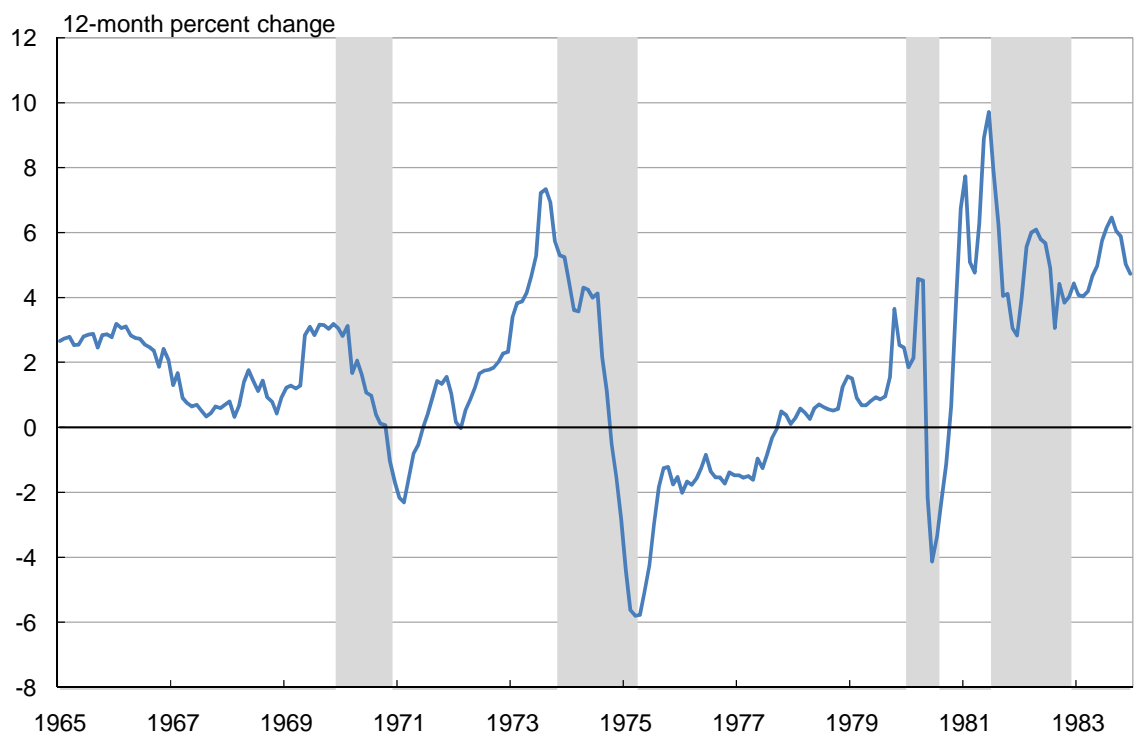

Note: The real federal funds rate equals the effective federal funds rate minus the percent change in core $\mathrm{CPI}$ over the past 12 months.

Sources: Bureau of Labor Statistics; Federal Reserve Board 
Figure 3: Exchange Rates

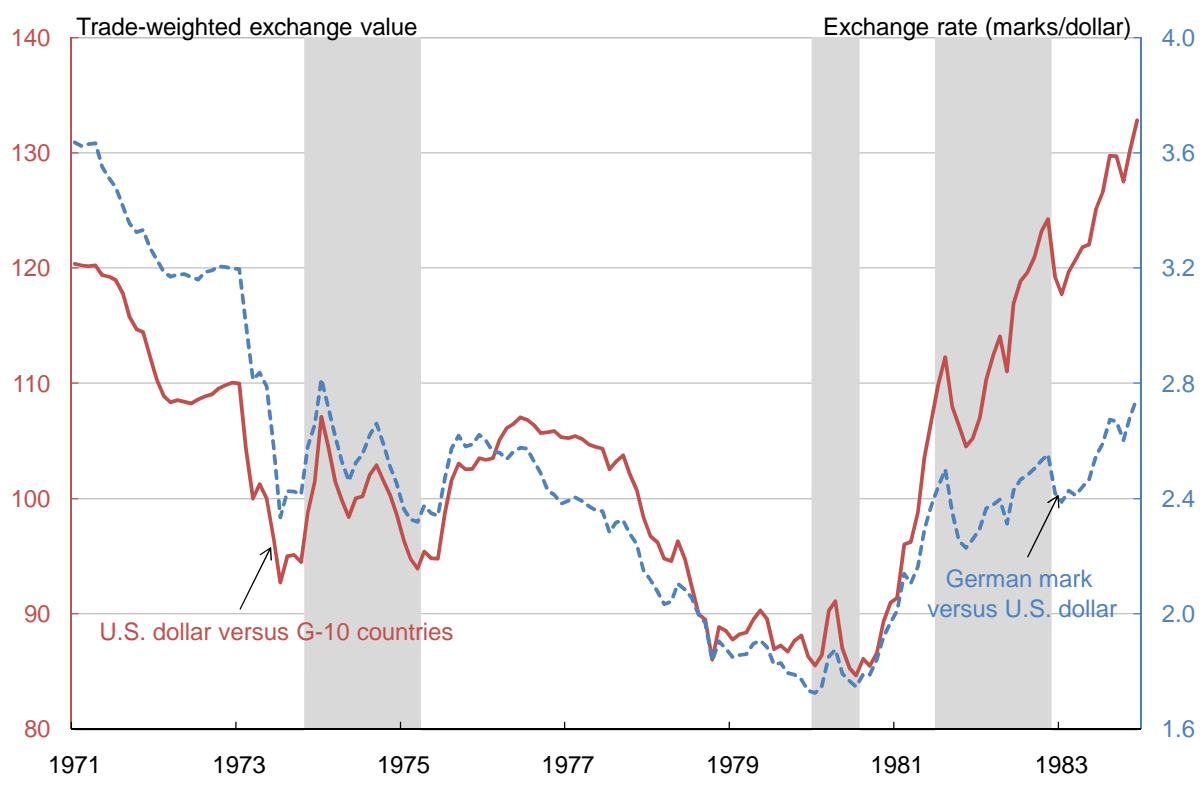

Source: Federal Reserve Board

Figure 4: Inflation Trends

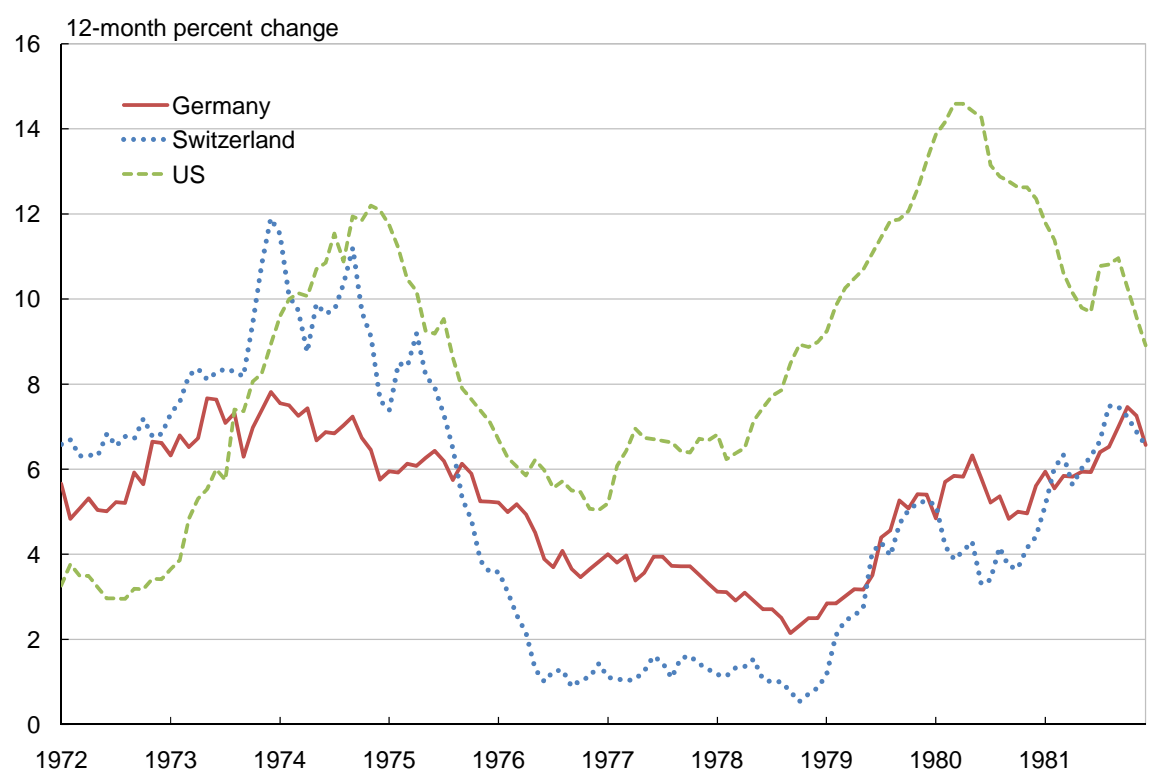

Sources: Deutsche Bundesbank; Swiss Federal Statistical Office; Bureau of Labor Statistics 
Figure 5: Federal Reserve Foreign Currency Balances (\$-millions; year end)

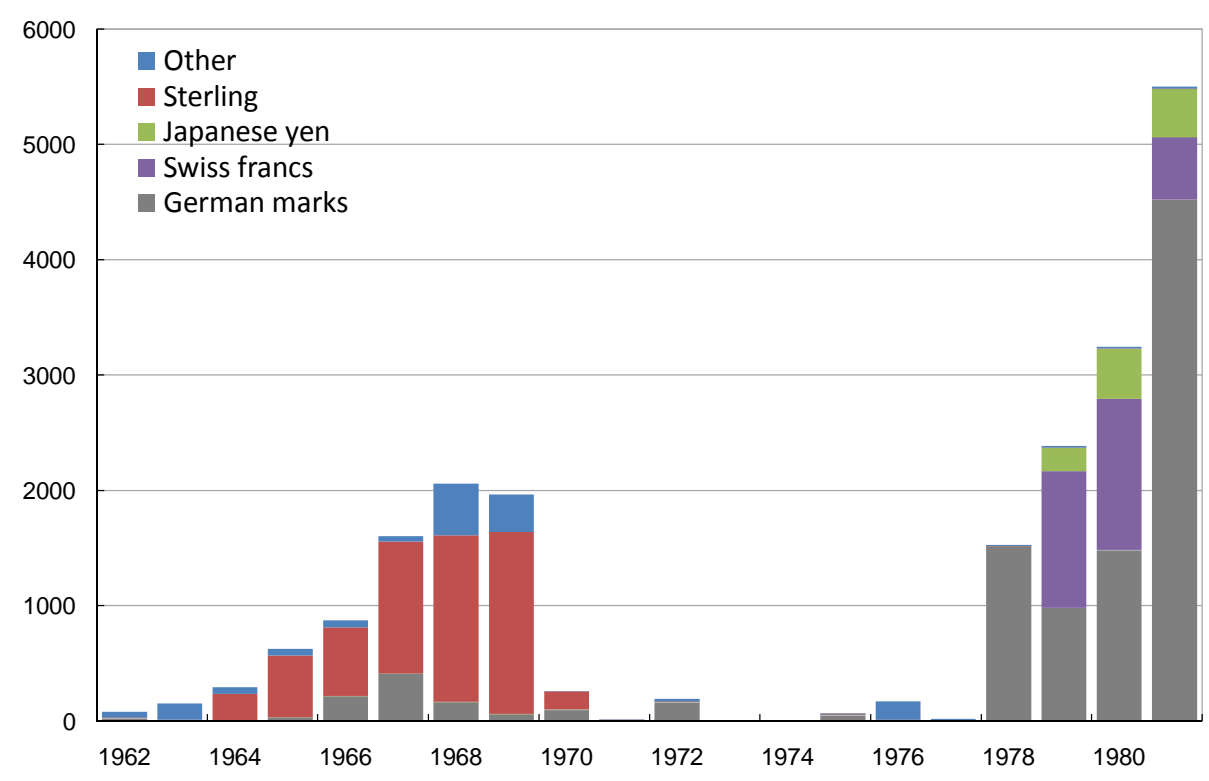

Source: Federal Reserve System

Figure 6: U.S. Treasury Foreign Currency Balances

(\$-millions; year end)

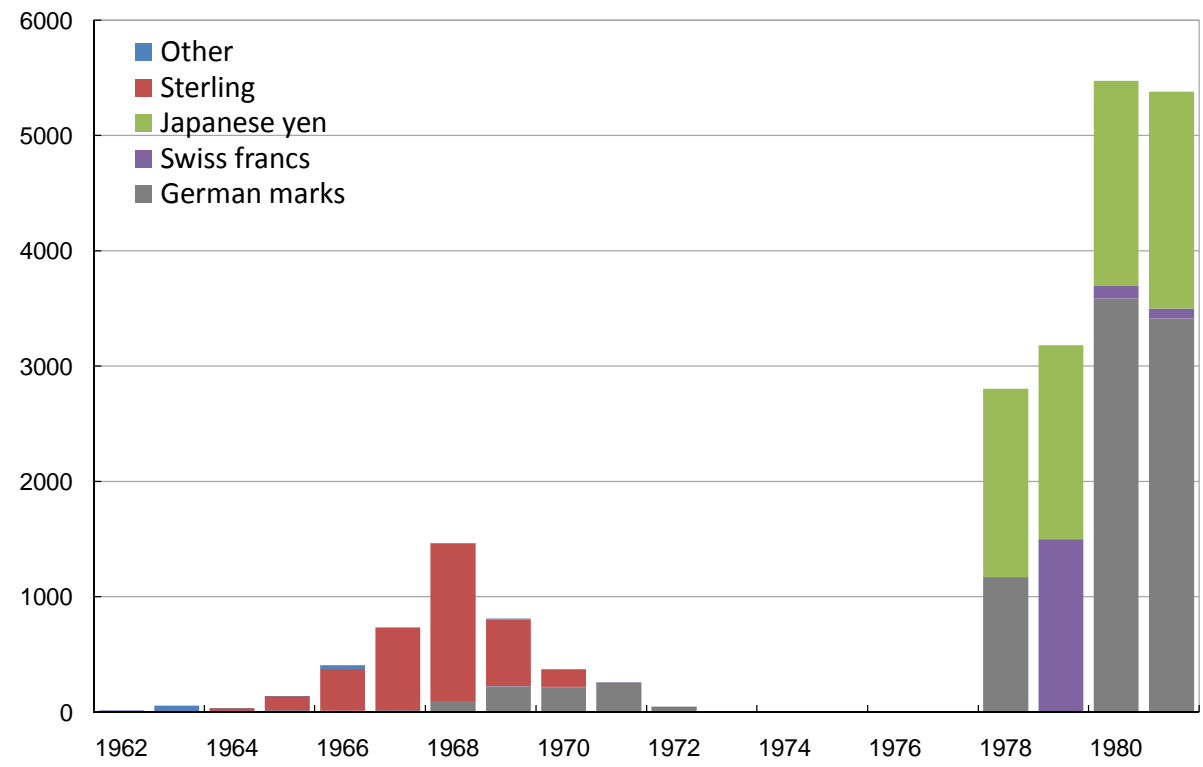

Source: Federal Reserve System 
Figure 7: Federal Reserve Authorization for SWAP Lines

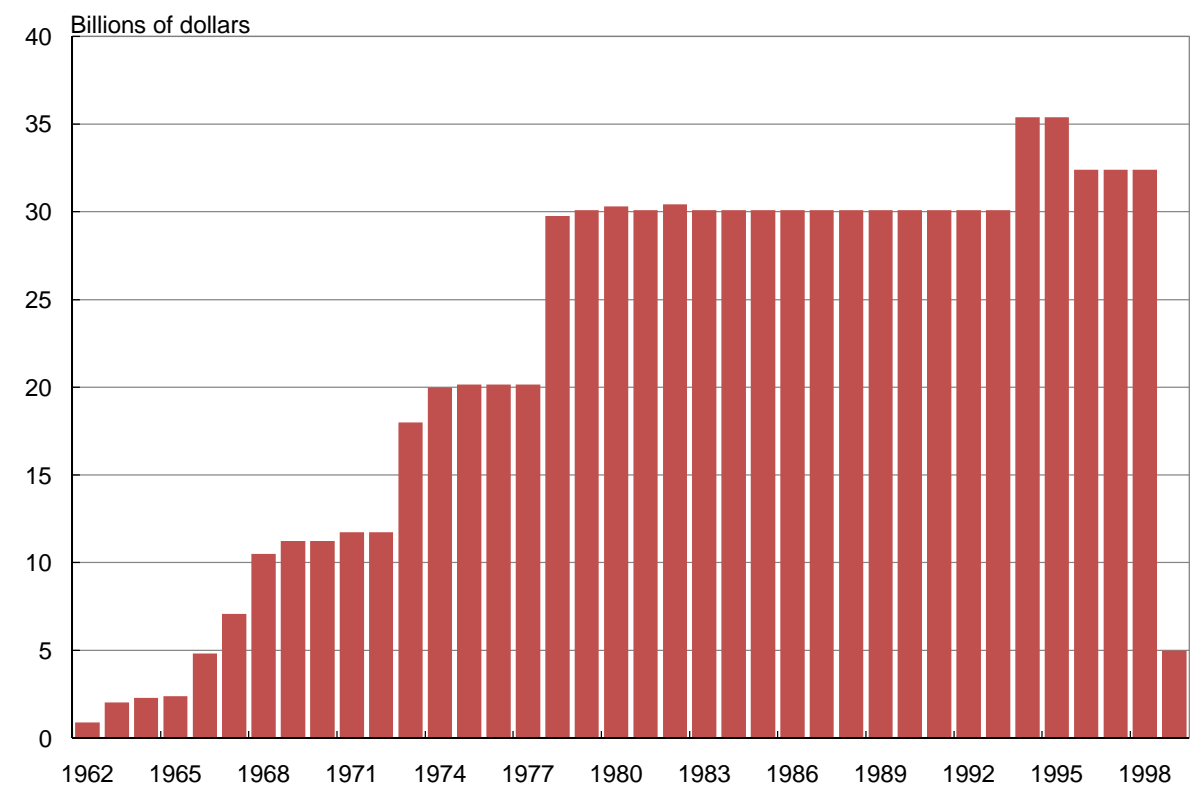

Source: Federal Reserve System 
Figure 8: U.S. Interventions against German Marks

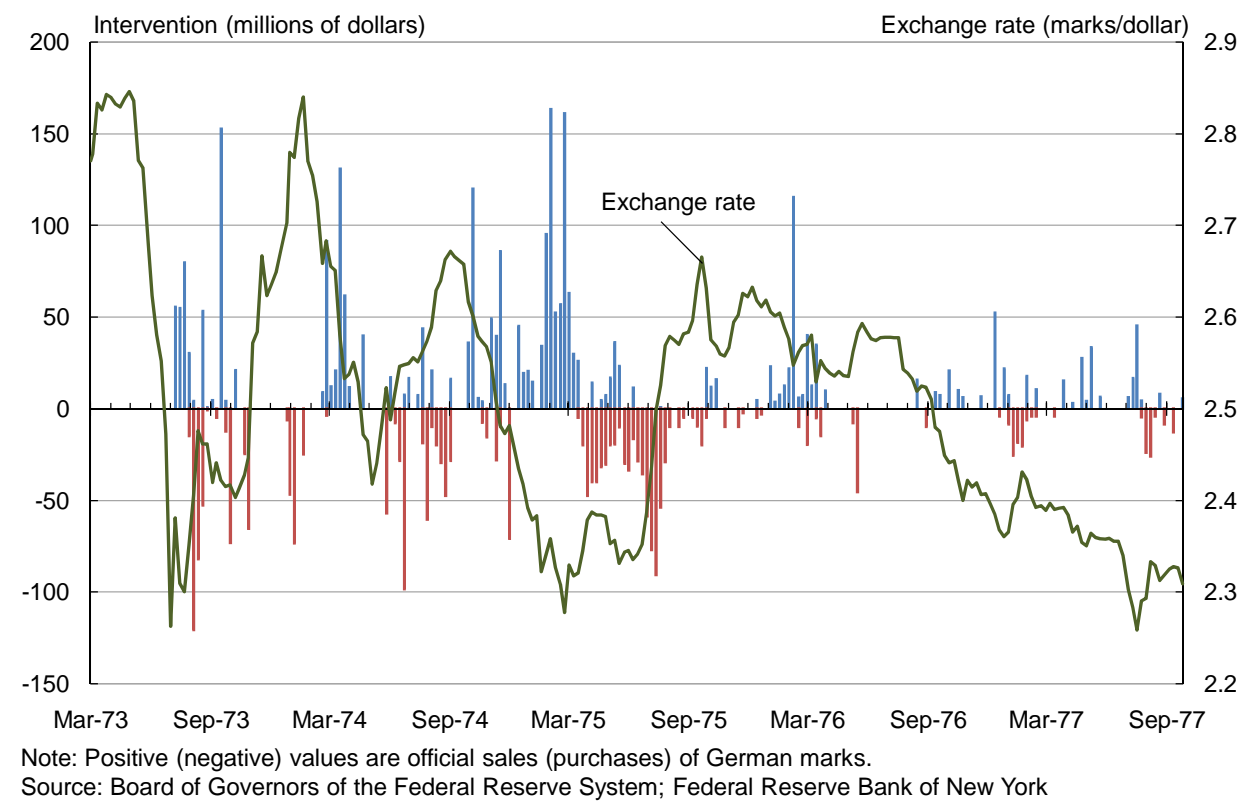

Figure 9: U.S. Interventions against German Mark

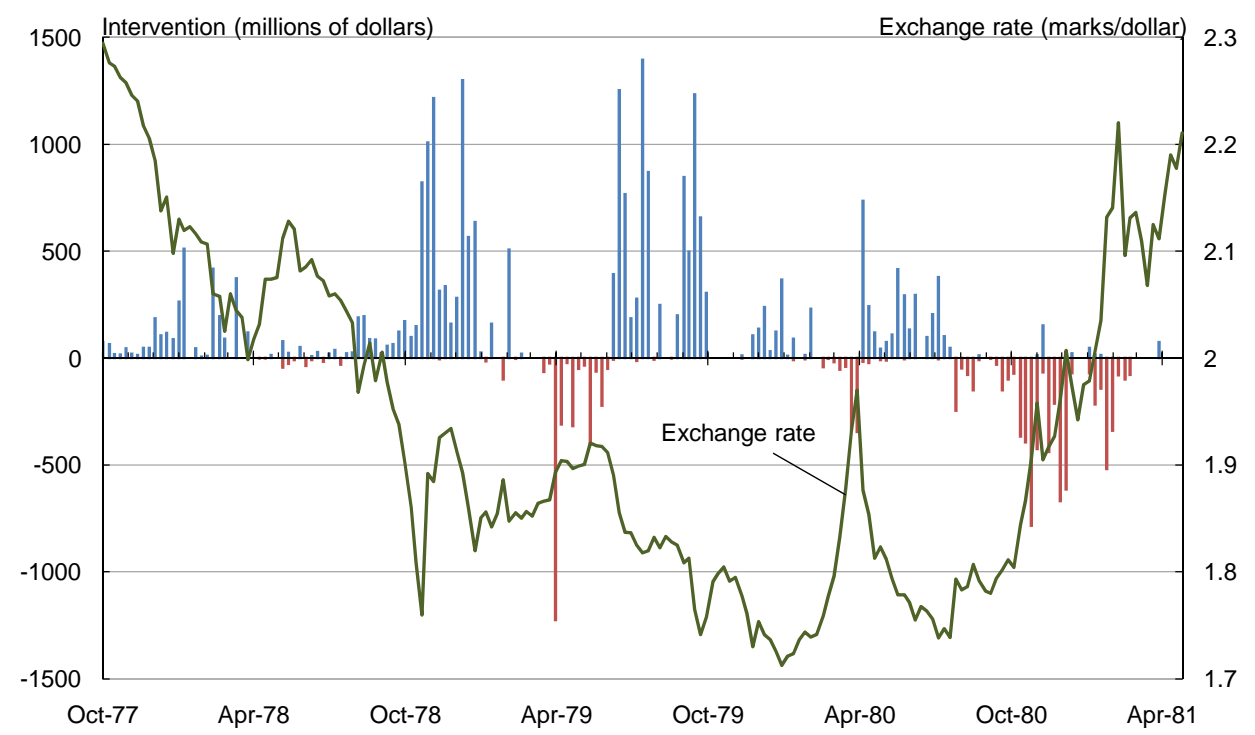

Note: Positive (negative) values are official sales (purchases) of German marks.

Source: Board of Governors of the Federal Reserve System; Federal Reserve Bank of New York 
Figure 10: U.S. Treasury Sources \& Uses of German Marks

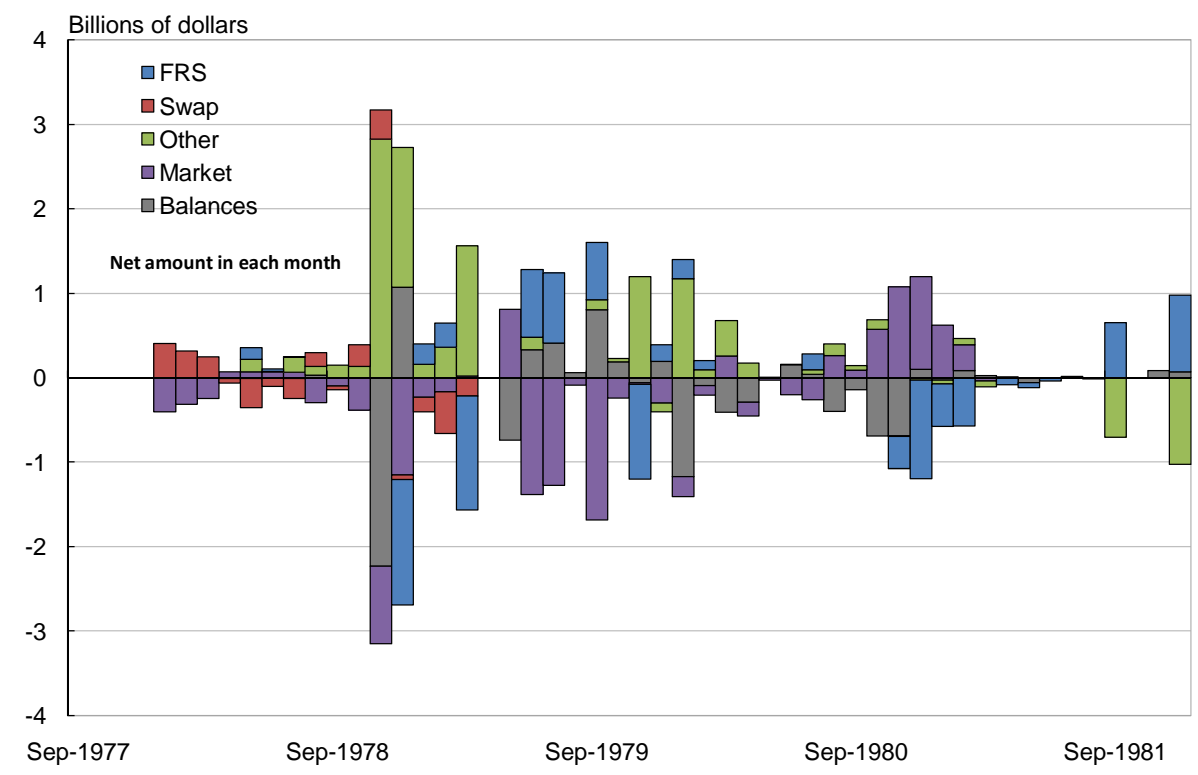

Figure 11: Fed Sources \& Uses of German Marks

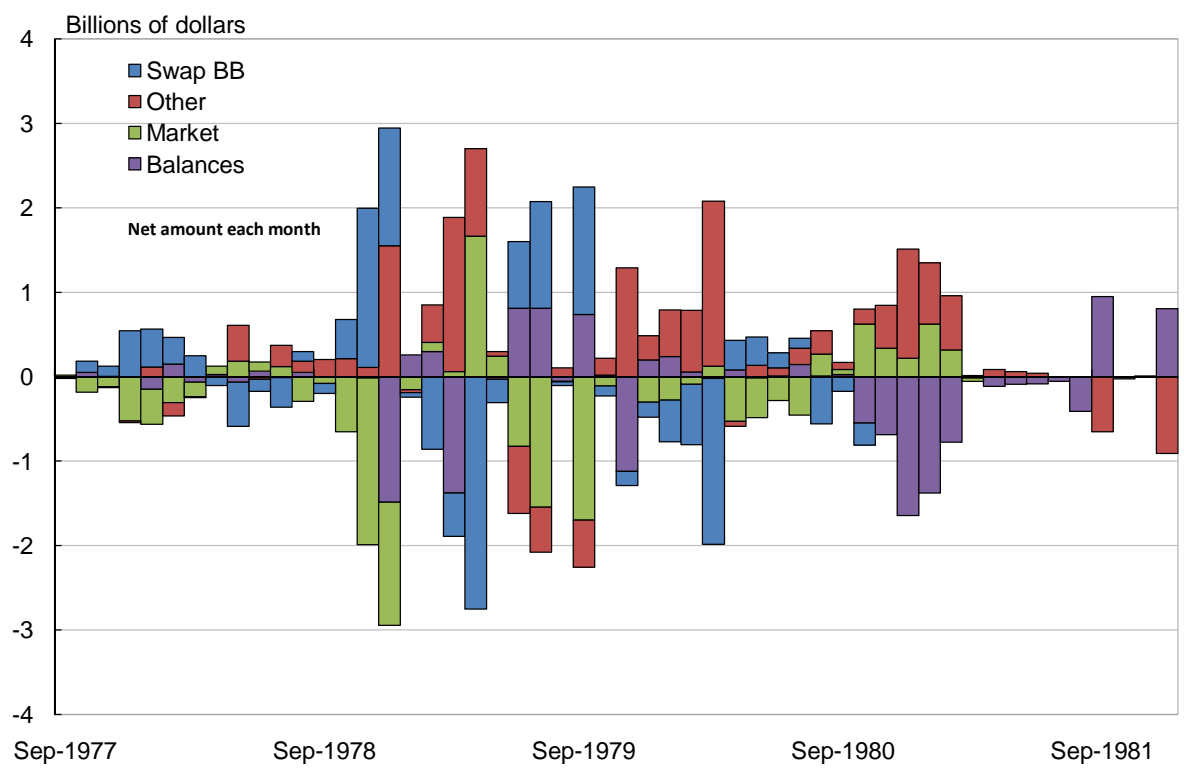


Figure 12: Treasury Foreign-Currency Securities

(\$-millions equivalent, year end)

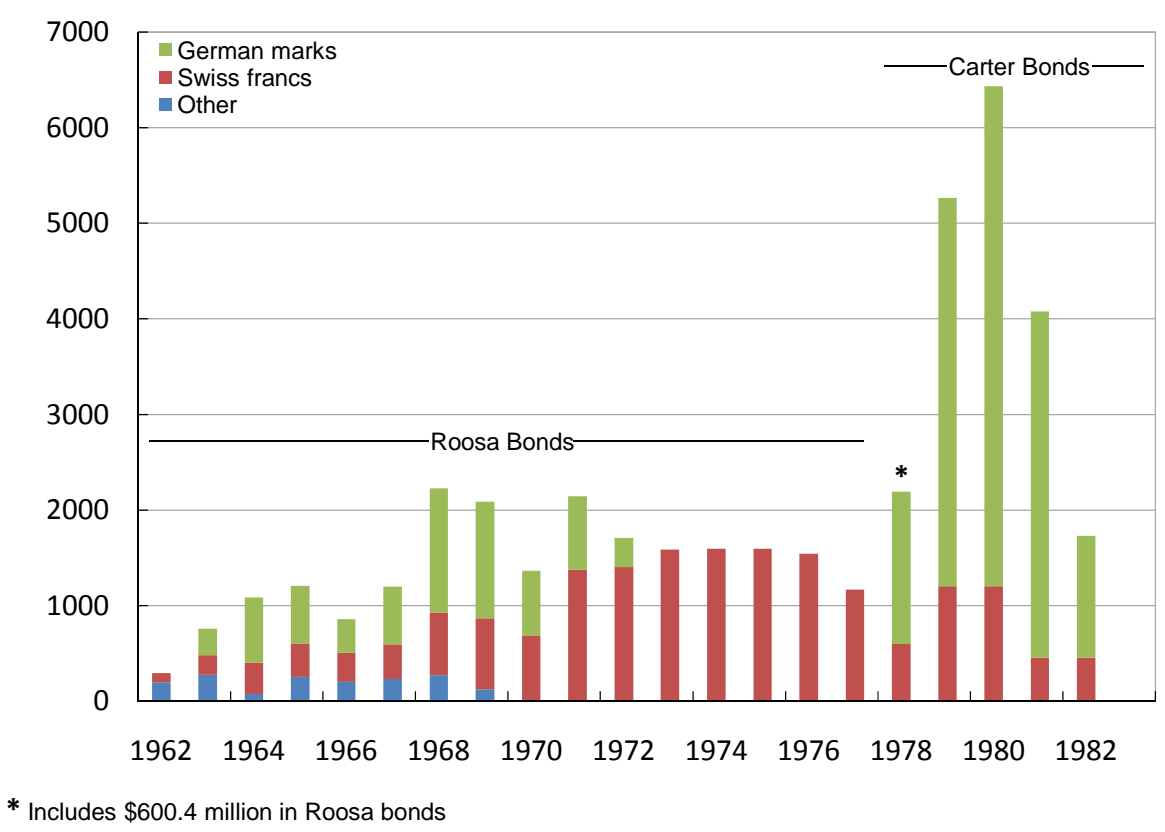

Figure 13: Warehousing : Currencies Held at the Fed

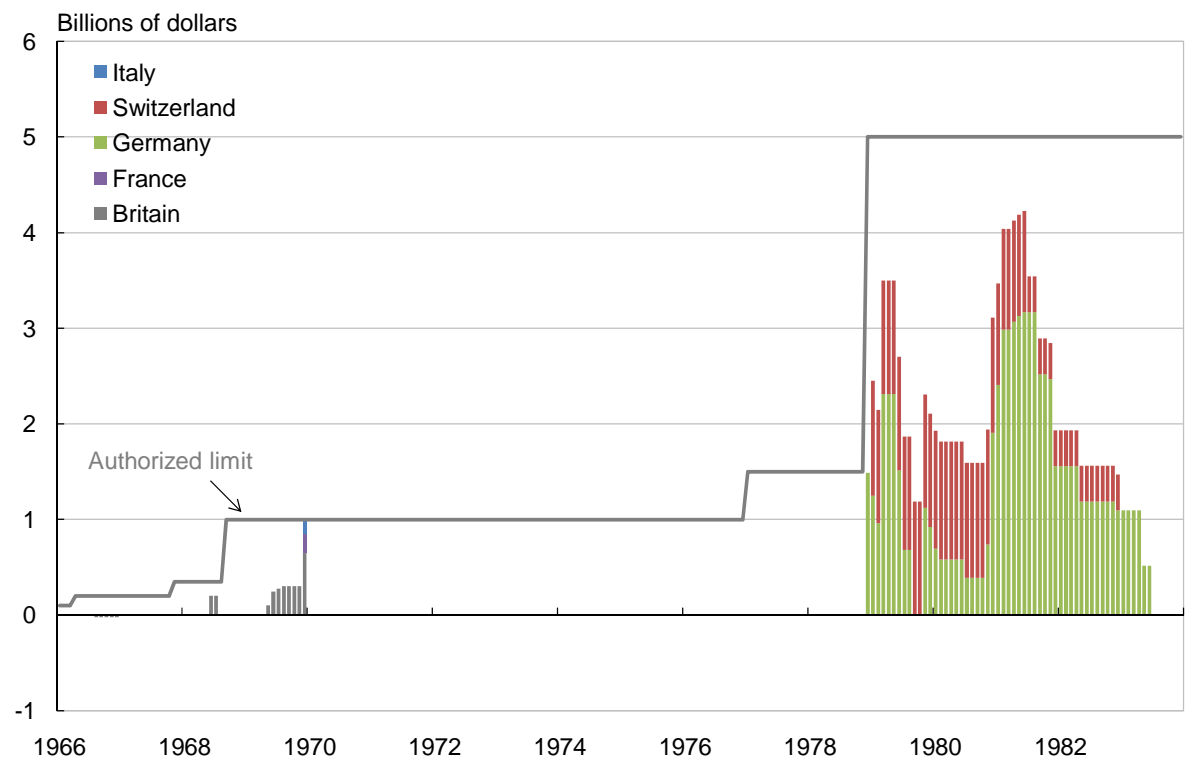


Table 1: INTERVENTION TO SUPPORT THE DOLLAR

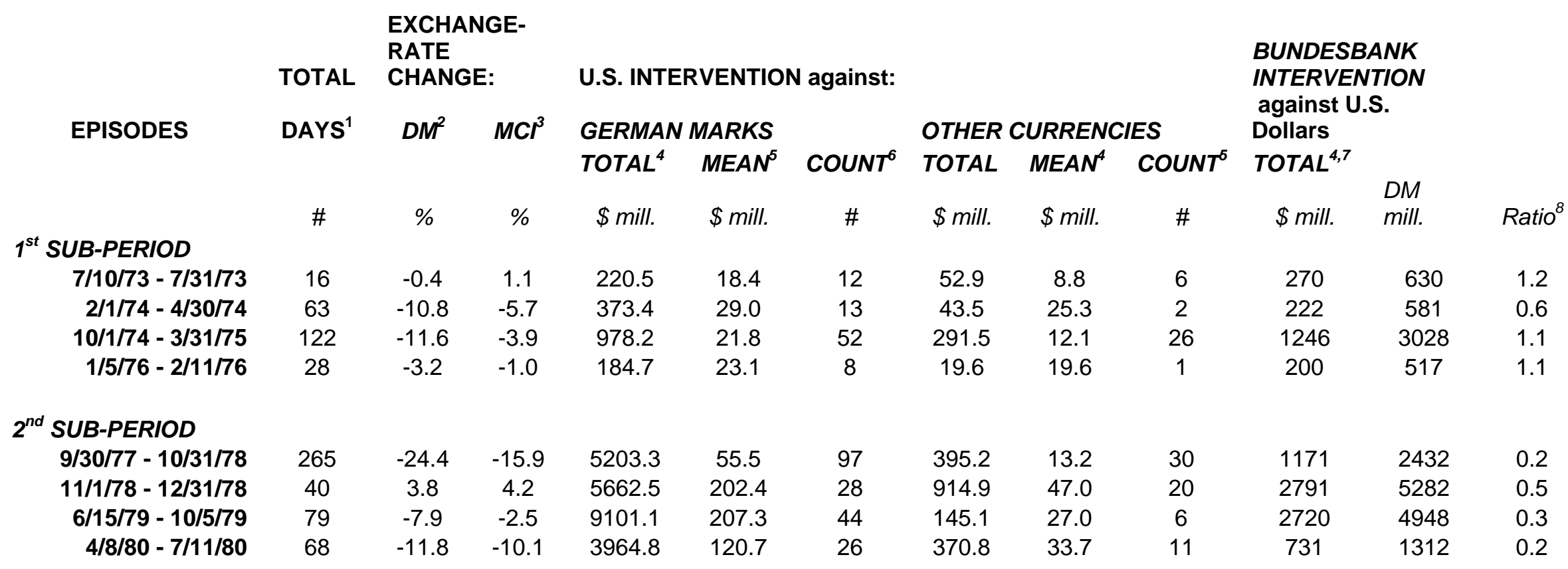

Footnotes:

1 Business days between first and last intervention. German marks per U.S.

2 dollar

3 Board of Governors' Major Currency Index, negative value indicates dollar depreciation.

4 Positive and negative values are net purchases and sales of dollars, respectively.

5 Average number of dollars purchased over days in episode.

6 Number of days on which dollars were purchased during episode.

7 Converted to dollars using average daily exchange rate for the period.

8 Ratio of Bundesbank purchases of dollars to U.S. purchases of dollars.

Sources: Board of Governors of the Federal Reserve System, Deutsche Bundesbank, Truman (1980) 
TABLE 2: SUCCESS COUNTS FOR U.S. INTERVENTION 2 March 1973 to 14 September 1977

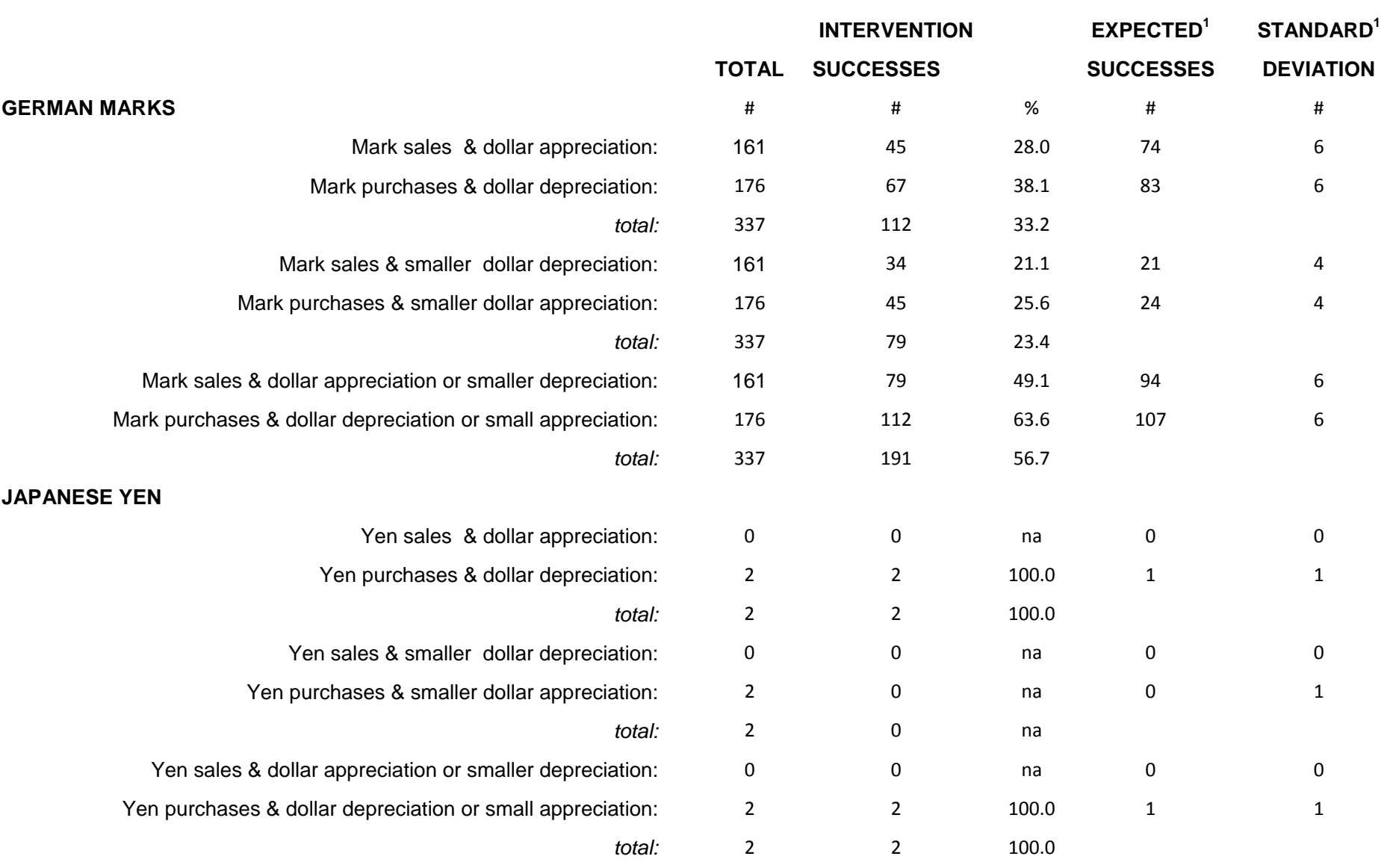

1. Assumes that the success count is a hypergeometric random variable.

See appendix for detail. 
TABLE 3: SUCCESS COUNTS FOR U.S. INTERVENTION 15 September 1977 to 5 October 1979

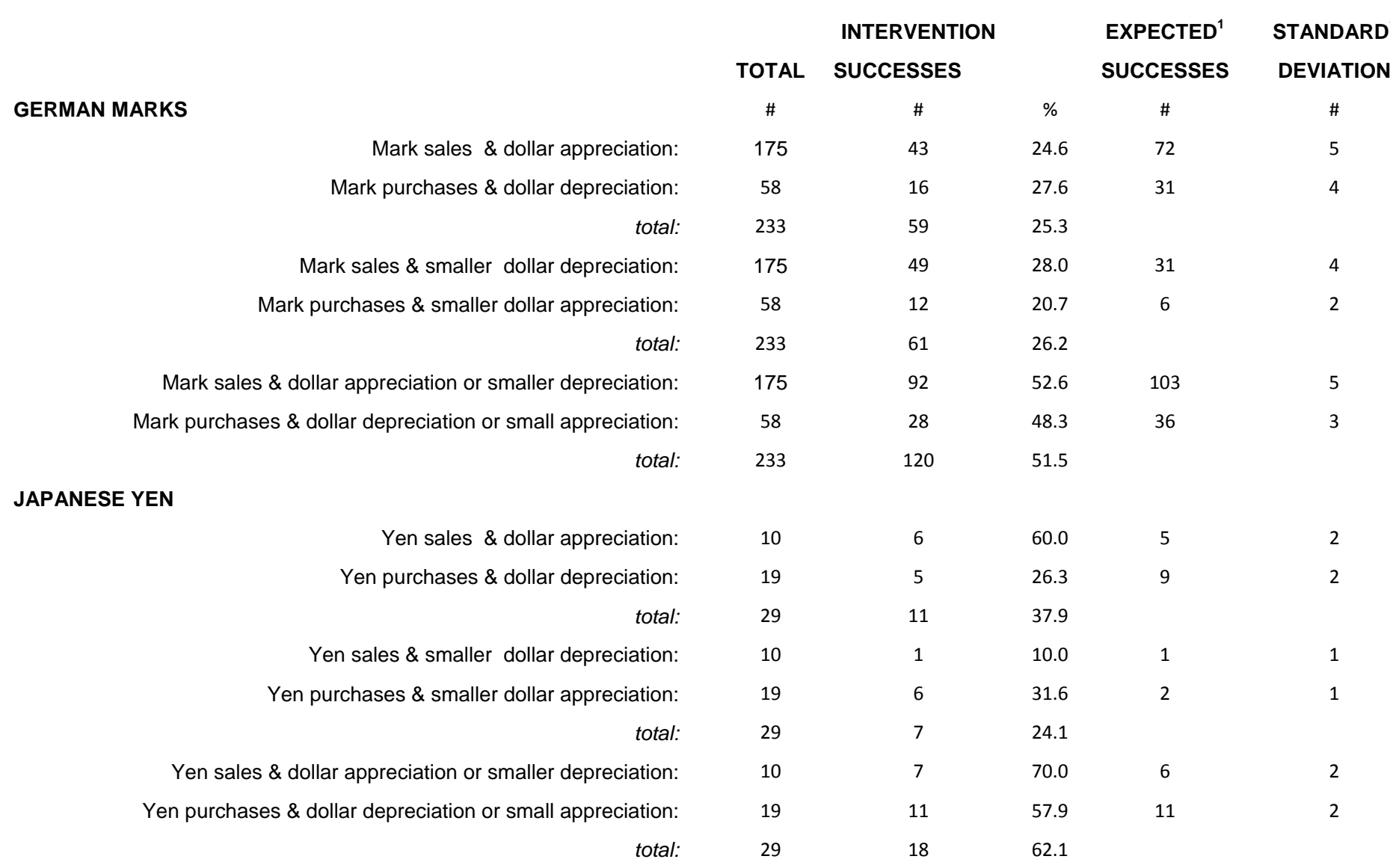

1. Assumes that the success count is a hypergeometric random variable.

See appendix for detail. 
TABLE 4: SUCCESS COUNTS FOR U.S. INTERVENTION 8 October 1979 to 17 April 1981

\begin{tabular}{|c|c|c|c|c|c|}
\hline & & INTERVENTION & & EXPECTED ${ }^{1}$ & STANDARD $^{1}$ \\
\hline & TOTAL & SUCCESSES & & SUCCESSES & DEVIATION \\
\hline GERMAN MARKS & $\#$ & \# & $\%$ & \# & $\#$ \\
\hline Mark sales \& dollar appreciation: & 55 & 15 & 27.3 & 28 & 3 \\
\hline Mark purchases \& dollar depreciation: & 114 & 41 & 36.0 & 50 & 4 \\
\hline total: & 169 & 56 & 33.1 & & \\
\hline Mark sales \& smaller dollar depreciation: & 55 & 17 & 30.9 & 7 & 2 \\
\hline Mark purchases \& smaller dollar appreciation: & 114 & 25 & 21.9 & 17 & 3 \\
\hline total: & 169 & 42 & 24.9 & & \\
\hline Mark sales \& dollar appreciation or smaller depreciation: & 55 & 32 & 58.2 & 35 & 3 \\
\hline Mark purchases \& dollar depreciation or small appreciation: & 114 & 66 & 57.9 & 68 & 4 \\
\hline total: & 169 & 98 & 58.0 & & \\
\hline \multicolumn{6}{|l|}{ JAPANESE YEN } \\
\hline Yen sales \& dollar appreciation: & 1 & 1 & 100.0 & 1 & 0 \\
\hline Yen purchases \& dollar depreciation: & 10 & 4 & 40.0 & 4 & 2 \\
\hline total: & 11 & 5 & 45.5 & & \\
\hline Yen sales \& smaller dollar depreciation: & 1 & 0 & 0.0 & 0 & 0 \\
\hline Yen purchases \& smaller dollar appreciation: & 10 & 1 & 10.0 & 1 & 1 \\
\hline total: & 11 & 1 & 9.1 & & \\
\hline Yen sales \& dollar appreciation or smaller depreciation: & 1 & 1 & 100.0 & 1 & 0 \\
\hline Yen purchases \& dollar depreciation or small appreciation: & 10 & 5 & 50.0 & 6 & 2 \\
\hline total: & 11 & 6 & 54.5 & & \\
\hline
\end{tabular}

1. Assumes that the success count is a hypergeometric random variable.

See appendix for detail. 


\section{References}

\section{Abbreviations used in text for references:}

BIS: Bank for International Settlements

Bulletin: Treasury and Federal Reserve Foreign Exchange Operations, or Treasury and Federal Reserve Foreign Exchange Operations: Interim Report.

CEA: Council of Economic Advisors

Desk Report: Federal Reserve Bank of New York, Annual Report on Operations in Foreign Currencies

FOMC Minutes: Federal Open Market Committee, Minutes of the Federal Open Market Committee.

FOMC Transcripts: Federal Open Market Committee. Transcripts of Federal Open Market Committee.

NYT: New York Times

Task Force: Task Force on System Foreign Currency Operations.

\section{References:}

Adams, D. and D. Henderson. 1983. "Definition and Measurement of Exchange Market Intervention.” Board of Governors of the Federal Reserve System, Staff Studies No. 126.

Axilrod, and Alan R. Holmes. 1979. "Holding of Foreign Currency Balances,” memorandum to the Federal Open Market Committee. April 10.

Barsky, R.B. and L. Kilian. 2004. “Oil and the Macroeconomy,” Journal of Economic Perspectives 18 (1).

Bordo, Michael D. and Barry Eichengreen. 2008. "Bretton Woods And The Great Inflation,” NBER Working Paper 14532, (December).

Burns, Arthur F. 1973. "Statement to the Subcommittee on International Economics of the Joint Economic Committee, June 27, 1973,” Federal Reserve Bulletin 59 (July): $508-512$.

Chari, Varadarajan, Lawrence J. Christiano and Martin Eichenbaum. 1998.

"Expectations, Traps and Discretion,” Journal of Economic Theory 81(2): 462492.

Christiano, Lawrence J. and Christopher Gust. 2000. “The Expectations Trap,” Federal Reserve Bank of Chicago Economic Perspectives 24(2): 21-39. 
Clarida, Richard, Jordi Gali, and Mark Gertler. 2000. "Monetary Policy Rules and Macroeconomic Stability: Evidence and Some Theory,” The Quarterly Journal of Economics, 115(1):147-180.

de Vries, Margaret Garritsen. The International Monetary Fund 1972-1978, Cooperation on Trial, Vol. I, International Monetary Fund: Washington, D.C., 1985.

Dooley, Michael P. and Jeffrey R. Shafer. 1983. “Analysis of Short-Run Exchange Rate Behavior: March 1973 to November 1981,” in David Bigman and Teizo Taya, (eds.) Floating Exchange Rates and the State of World Trade Payments, Ballinger: Cambridge, Mass.

Federal Open Market Committee. Minutes of the Federal Open Market Committee, 10 January 1961- 16 March 1976. Board of Governors of the Federal Reserve System: Washington, D. C.

Federal Open Market Committee Meeting Transcripts, 4/20/76(1) Box G44, Arthur Burns Papers, 1969-78, Gerald R. Ford Library.

Federal Open Market Committee Meeting Transcripts, 7/19/77(1) Box G52, Arthur Burns Papers, 1969-78, Gerald R. Ford Library.

Federal Open Market Committee Meeting Transcripts, 10/17-18/77(1) Box G54, Arthur Burns Papers, 1969-78, Gerald R. Ford Library.

Federal Open Market Committee. Transcripts of the Federal Open Market Committee, 5 January 1978 - 16 December 1997. Board of Governors of the Federal Reserve System: Washington, D. C.

Federal Reserve Bank of New York, Annual Report on Operations in Foreign Currencies, unpublished report submitted by the Special Manager of the System Open Market Account for Foreign Currency Operations to the Federal Open Market Committee, 1967.

Greene, Margaret L. “U.S. Experience with Exchange Market Intervention: January March 1975. Board of Governors of the Federal Reserve System, Staff Studies \#127 (August 1984).

Greene, Margaret L. “U.S. Experience with Exchange Market Intervention: September 1977 - December 1979. Board of Governors of the Federal Reserve System, Staff Studies \#128 (October 1984).

Greene, Margaret L. “U.S. Experience with Exchange Market Intervention: October 1980 - September 1981 - December 1979. Board of Governors of the Federal Reserve System, Staff Studies \#129 (August 1984). 
Hackley, Howard. 1969. "Legal Aspects of Proposals for Assisting Treasury in Connection with Cash and Debt Ceiling Problems.” Board of Governors internal memorandum. January 31.

Hetzel, Robert L. 2002. "German Monetary History in the Second Half of the Twentieth Century: From the Deutsche Mark to the Euro.” Federal Reserve Bank of Richmond Economic Quarterly, 88(2): 29-64.

Hetzel, Robert L. 2008. The Monetary Policy of the Federal Reserve, A History. Cambridge University Press: New York.

Holmes, Alan R. and Scott E. Pardee. 1979. "Holdings of Foreign Currency Balances by the Federal Reserve.” Memorandum to the FOMC, (10 April).

Hooper, Peter. 1977. "Procedures for Federal Reserve System Foreign Currency Operations,” internal memorandum of the Board of Governors, (April 28).

Mayer, Thomas. 1999. Monetary Policy and the Great Inflation in the United States, The Federal Reserve and the Failure of Macroeconomic Policy, 1965-79, Cheltenham, U.K.: Edward Elgar. [HG 539.M39 1999].

McKinnon, Ronald I. 1976. Floating Foreign Exchange Rates 1973-74: The Emperor's New Clothes. In K. Brunner and A. Meltzer, eds. Carnegie-Rochester Conference Series on Public Policy. North-Holland. 79 - 114.

Meltzer, Allan H. 2005. “Origins of the Great Inflation,” Federal Reserve Bank of St. Louis Review (March/April, part 2): 145-175.

Morton, John E. 1977. "Background Information on System 'Warehousing' of Foreign Currency.” Internal memorandum to Governor Wallich. Board of Governors of the Federal Reserve System. 14 January.

Morton, John E. and Edwin M. Truman. 1979. "U.S. Holdings of Foreign Currency Balances.” Memorandum to the FOMC, (10 April).

Orphanides, Athanasios. 2002. "Monetary-Policy Rules and the Great Inflation," American Economic Review Papers and Proceedings 92(2): 115-120.

Orphanides, Athanasios. 2003. "Historical Monetary Policy Analysis and the Taylor Rule,” Finance and Economic Discussion Series 2003-36 (July).

Pardee, Scott E. 1973. "Review of Techniques for Intervention in the New York Exchange Market,” unpublished Federal Reserve Bank of New York office correspondence to Mr. Coombs (September 17).

Romer, Christina D. and David H. Romer. 2002. “The Evolution of Economic Understanding and Postwar Stabilization Policy,” in Rethinking Stabilization Policy, A Symposium Sponsored by The Federal Reserve Bank of Kansas. Jackson Hole, Wyoming, August 29-31, 2002 [HB 3732 .R48].

Schwartz, Anna J. 1983. "The Postwar Institutional Evolution of the International Monetary System.” in Dooley et al. (eds.), The International Transmission of Inflation. University of Chicago Press: Chicago. 
Schwartz, Anna J. 1997. "From Obscurity to Notoriety: A Biography of the Exchange Stabilization Fund,” Journal of Money, Credit, and Banking, 29 (2): 135-153.

Solomon, Robert. 1982. “The International Monetary System, 1945-198.” New York: Harper \& Row.

Sprinkel, Beryl W. 1981. Testimony before the Joint Economic Committee, Congress of the United States (Ninety-Seventh Congress; First Session) May 4, 1981. Washington, D.C.: U.S. Government Printing Office, pp. 1 - 36x.

Stevens, Edward. 1989. "Monetary Impacts of U.S. Dollar Sales in the Foreign Exchange Market.” Federal Reserve Bank of Cleveland unpublished internal memorandum. July 5.

Task Force on System Foreign Currency Operations. "Historical Review U.S. Official Holdings of Foreign Currencies,” Paper \#8. Foreign Exchange Department, Federal Reserve Bank of New York. 16 January 1990.

Task Force on System Foreign Currency Operations. "Historical Review of Reciprocal Currency Arrangements (The 'Swap’ Network),” Paper \#9. Foreign Exchange Department, Federal Reserve Bank of New York. 24 January 1990.

Task Force on System Foreign Currency Operations. "Review of Approaches and Tactics of Intervention in the Context of Changing Market Conditions Policy and Objectives,” Paper \#5. 18 January 1990.

“Treasury and Federal Reserve Foreign Exchange Operations," Federal Reserve Bulletin, Board of Governors of the Federal Reserve System: Washington, D. C. various issues.

“Treasury and Federal Reserve Foreign Exchange Operations: Interim Report,” Federal Reserve Bulletin, Board of Governors of the Federal Reserve System: Washington, D. C. various issues.

Truman, Edwin M. 1980. "Background Material on System Foreign Currency Operations," memorandum to the FOMC. (11 December).

Truman, Edwin M. 2005. "Reflections,” Federal Reserve Bank of St. Louis Review 87(2, Part 2): 353-57.

Volcker, Paul A. 1976. "Priorities for the International Monetary System,” Federal Reserve Bank of New York Monthly Review 58(January): 3-9.

Volcker, Paul A. and Toyoo Gyohten. 1992. Changing Fortunes, The World's Money and the Threat to American Leadership. New York: Times Books. [HG 3881.V65 1992] . 


\section{ENDNOTES}

1 Most of the liquidity entered Germany. See Hetzel (2002) for brief history and useful references.

2 Greene (\#127 August 1984, \#128 October 1984 and \#129, August 1984) provides detailed surveys of U.S. interventions over select intervals between January 1975 and September 1981. Greene was an Assistant Vice President in charge of the Foreign Exchange Desk over these years.

3 This paragraph follows Bordo and Eichengreen (2009). See also: Romer and Romer 2002, p. 57, and Hetzel 2008, p. 68.

${ }^{4}$ Orphanides (2002, p. 118) estimated a Taylor rule for the period, and found that the coefficient on the unemployment gap was substantially greater than the coefficient on the inflation term. This result suggests that policy makers gave more weight to the former than the latter in their policy decisions.

${ }^{5}$ Barsky and Kilian (2004, p. 126) argue that OPEC's actions in late 1973 were a reaction to high U.S. inflation rates in the late 1960s and early 1970s. The resulting dollar depreciation eroded the real purchasing power of the cartel's revenues and strengthened OPEC by increasing the demand for oil outside of the United States. Similarly, the growing lack of confidence in U.S. monetary policy and the fear of inflation that emerged over the 1970s may have distorted economic decisions in ways that further eroded growth in the nation's potential to produce.

${ }^{6}$ The United States increased the official gold price from $\$ 35$ per ounce to \$38 per ounce. Chapter 4 discusses the collapse of Bretton Woods.

${ }^{7}$ The System also had intervened in July 1972. For a discussion see chapter 4.

${ }^{8}$ These financial controls included the interest equalization tax, controls imposed through the Office of Foreign Direct Investment, and the Federal Reserve's Voluntary Credit Restraint Program.

9 The Smithsonian Agreement allowed for wider (21/4\%) bands on either side of the new dollar parities. This change conceivably permitted European currencies to fluctuate as much as $4 \frac{1}{2} \%$ against each other. At their 7 March 1972 Basle conference, the six EEC members agreed to limit fluctuations in their currencies to $2 \frac{1}{4} \%$. See also chapter 4 .

${ }^{10}$ Treasury Secretary Connally did not want reform discussions to take place within the G10 because he believed that the G10 was stacked against U.S. interests (Solomon, 1982, p. 219). 
${ }^{11}$ In early 1973, Germany, the United Kingdom, and the United States favored a temporary float, while Belgium, France, Japan, the Netherlands, and the developing countries most strongly opposed floating (de Vries, 1985, pp. 187-197).

12 The FOMC Minutes (19-20 March 1973, pp. 49 - 71) contain a discussion of this meeting, which Chairman Burns, Governors Daane and Bryant, and Special Manager Coombs attended. This paragraph draws on that discussion.

${ }^{13}$ Chapter 4 discusses this problem and its resolution.

${ }^{14}$ Under Bretton Woods, except for the case of revaluation, the borrower assumed any exchange risk associated with exchange-rate movements within intervention bands.

15 The FOMC had authorized Coombs to negotiate an increase in the swap lines on 20 March 1973, (FOMC, Minutes, 19-20 March 1973, p. 87)

16 After December 1980, any country drawing on the swap lines agreed to take the full exchange risk in exchange for changes in the interest rates (Task Force Paper \#9, 24 January 1990, p. 7)

17 The official U.S. intervention data does not draw a distinction between active and passive interventions.

18 The remainder of this section draws heavily on Hooper (1977) and Pardee (1973).

${ }^{19}$ In 1981, the System placed simultaneous bid and offer rates in the market. "In all, the Trading Desk at the Federal Reserve Bank of New York operated in the market as a net buyer of marks on nine of fourteen trading days between February 2 and 23.” [emphasis added] (Bulletin, June 1981, pp. 486-487).

20 Green $(\# 127,1984)$ analyzes the U.S. interventions from January through March 1975.

${ }^{21}$ The U.S. Treasury purchased German marks from the market in October 1973 and January 1974 and used these funds to retire outstanding mark-denominated securities with the private sector and repay mark obligations with the IMF. The Treasury also paid marks to a foreign central bank. The Treasury added a small amount to its balances in January 1974, but sold this in the market during February 1974.

22 During each of the active intervention episodes of dollar sales reported in table 1 , the dollar depreciated against the German mark, and likewise, the dollar also depreciated on a trade-weighted basis against the currencies of the major developed countries in every episode except the first.

23 This paragraph draws on Green \#128, October 1984, pp. 10 - 12. 
${ }^{24}$ Burns had expressed uncertainty about intervention at least as early as July 1977. After Holmes claimed that exchange rates could not be justified in terms of fundamentals, Burn said, "In view of some acceleration in the inflation rate in our country, I think markets are behaving quite rationally. And now the implication of that for operations of the Desk are not entirely clear, but when you speak to disorderly markets, it's one thing, when you comment on fundamentals well, you may be right, but that's not my present interpretation of what is going on.” (FOMC, Transcripts, 19 July 1977, tape A, p. 3)

25 Burns' views are found in the FOMC Transcripts 5 January 1978 (p. 8) and 17 January 1978 (pp. 5-15).

26 Burns chaired the 28 February 1978 FOMC meeting because Miller, who was to have taken over at this point, was still testifying to Congress.

27 Our data also indicate that between November 1976 and January 1979, the System continuously sold marks off-market to some other official entity for Swiss francs to retire outstanding debt obligations. These sales totaled $\$ 353$ billion and were largely financed out of swap borrowings and transactions with the market (see chapter 4).

28 In January 1974, the Desk bought \$4.6 million worth of Japanese yen for the Treasury’s account (Bulletin March 1974, p. 205).

29 Truman (2005, p. 354) reports that the "Bundesbank would not agree to the [1 November 1978] package ... until the Federal Reserve agreed to a decisive monetary policy move...”

30 The System also drew nearly $\$ 152$ billion on its Japanese yen swap line, and the Desk sold \$194 million yen by late November. The Treasury accounted for approximately $15 \%$ of the Japanese yen sales. Likewise the System drew \$707 million on its Swiss swap line in November and December and sold these funds in the market. The Treasury did not intervene in Swiss francs.

31 We explain warehousing below.

32 Volcker (January 1976, p 8) already expressed a similar assessment of earlier interventions: “...intervention is a tactic_-sometimes useful, sometimes not. By itself, it will accomplish little if not accompanied by appropriate domestic policies, by internal stability, and by some willingness to take account of international considerations in policymaking.”

33 Truman (2005, p. 354) indicates that Volcker “...received a harangue from the German authorities about getting the U.S. economic house in order.”

34 This section draws on Axilrod and Holmes (1979), Greene (\#129, August 1984), Holmes and Pardee (1979), Morton and Truman (1979) and Task Force Paper \#8 (1990). 
35 In late 1978, the System temporarily acquired a balance of $\$ 1.5$ billion equivalent German marks through a warehousing-type operation with the U.S. Treasury. Since warehousing operations are swaps, these funds did not increase the System's net open position in German marks, as holding reserves outright would have.

36 This, of course, was not the first time that the issue came up. In 1975, for example, Pardee recommended increasing the amount of working balances in German marks to avoid having to buy marks when the mark was trading at the top of the snake (FOMC, Minutes, 15 July 1975, p. 4).

37 Ironically, as Morton and Truman (10 April 1979, p. 5) warned, as the United States increased its own holdings of foreign exchange, it might have to undertake a greater amount of intervention. Other countries - particularly the smaller ones-might diversify their portfolios to hold fewer dollars. When the dollar subsequently depreciated, these foreign countries might be less inclined to intervene in dollars.

38 Axilrod may have overstated the significance of the Treasury's position because most of these funds were borrowed and had to be repaid. Foreign currency debt obligations equaled roughly half of the Treasury's foreign currency holdings (Task Force Paper \#8, 1990, Table 1).

39 The Treasury issued an additional $\$ 1.1$ billion equivalent German mark denominated Carter bonds in 1980.

40 The net open position equals foreign currency balances plus any net forward position less foreign currency liabilities.

41 Greene (\#129 August 1984, pp. 12-13) describes the Desk’s perception of market disorder: "In making judgments about conditions in the exchange market and the need for orderly market intervention, U.S. authorities considered many dimensions of trading. They evaluated the variability of the exchange rate itself as indicated, for example, by the magnitude and speed of rate changes within a day, day to day, cumulatively over several days or longer, and relative to perceived or known changes in the underlying economic fundamentals. They also evaluated market participants' perceptions of the risk of dealing as indicated, for instance, by the width of bid-asked spreads, the existence of large gaps between successive rate quotations, or an unwillingness on the part of market professionals to take currency into position even temporarily and thereby cushion the impact on the market of their customers' currency needs.”

42 Greene (\#129 August 1984, p.12) also notes that no institution that sold foreign exchange to the Desk had enough information to deduce the overall size of the operation on a given day.

43 As Holmes and Pardee (10 April 1979, pp. 9-10) note, central banks invest the funds that other central banks deposited with them in bills of their domestic governments. 
44 'In order that the System's weekly statement would not reflect too large an increase in its 'other assets,' the System at the end of its statement week of July 27 [1966] swapped \$88.2 million [equivalent] pounds for one day with the U.S. Treasury.” (Desk Report 1967, p.10) Why the Board did this is unclear, but it may have taken the action so that speculators would remain uncertain about the degree of support being offered to the pound.

45 On Coomb's desire to give the System a bigger say in the policy decisions, see (FOMC Minutes 14 November 1967, p. 31). As we show in chapters 4, 5, and 6, this was a frequent motive for maintaining and expanding the System's involvement in intervention.

46 During the last half of 1976, the Treasury undertook two swap drawings with England totaling $\$ 300$ million. These were repaid by the end of the year.

47 Exactly why the System began warehousing directly with the Treasury instead of the ESF remains unclear, since foreign currencies obtained from the sale of Carter bonds could easily be transferred from the Treasury to the ESF. Indeed, subsequent to the authorization, this may have been how the transactions were actually handled: "In the case [1978-79], the German marks and Swiss francs obtained from Carter bond sales were credited to the Treasury's General Fund Special Accounts at the Bundesbank and the Swiss National Bank, but then were immediately sold to the ESF. Since the ESF's resources were insufficient at the time to handle the transactions....the ability to warehouse the foreign currencies with the System enabled the ESF to acquire these bond proceeds from the General Fund.” (Task Force \#8 16 January 1990, p. 25)

48 Carter bonds allowed the Treasury to acquire foreign exchange without expanding the foreign money supply when the foreign exchange was sold for dollars.

49 The United States intervened on 30 March 1981, following an assassination attempt on President Reagan. See Greene (\#129 August 1984, p. 29) for a detailed account. 